\title{
LAS LEYES DEL REGADÍO MURCIANO: CONFLICTIVIDAD SOCIAL Y CODIFICACIÓN (1479-1503)
}

\author{
María Martínez Martínez* \\ Pedro Hernández Martínez** \\ Universidad de Murcia
}

\begin{abstract}
Resumen
Análisis del proceso de codificación de las Ordenanzas de la Huerta de Murcia durante el reinado de los Reyes Católicos. La elaboración de un "corpus" de leyes para el regadío murciano fue una lenta tarea por la divergencia de intereses económicos de la oligarquía concejil y las campañas granadinas. La crítica situación de la huerta, afectada por factores naturales (inundaciones y sequías) y sociales (corruptelas en el entramado institucional e incumplimiento de las normas) era una realidad desde los años setenta. La reforma legislativa de los monarcas finalizaba a principios del siglo XVI con la promulgación de las leyes del regadío murciano.
\end{abstract}

\section{Palabras Clave}

Regadío. Murcia. Ordenanzas. Reyes Católicos. Conflictos sociales.

\begin{abstract}
This paper analyses the process of compilation of legal dispositions corresponding to the huerta of Murcia during the reign of the Catholic kings. The creation of a body of laws for irrigation in Murcia Region was a time-consuming task due to conflicts of economic interests between the Council oligarchy and the Granada campaigns. Since 1470, the critical situation of the huerta, affected by natural factors (floods and droughts) and social (corruption in the institutional framework and non-compliance) was a reality. Legislative reforms undertaken by the kings ended at the beginning of the 16th century with the enactment of the ordinances or laws for the irrigation in Murcia Region.
\end{abstract}

\section{Keywords}

Irrigation. Murcia. Ordinances. Catholic Kings. Social unrest.

\section{Résumé}

Analyse du processus de codification des ordonnances de la "Huerta de Murcie" pendant le règne des Rois Catholiques. L'élaboration d'un "corpus" législatif consacré à l'irrigation dans le royaume de Murcie fut un travail de longue durée du fait de divergence d'intérêts économiques entre l'oligarchie municipale et les conséquences de la Guerre de Grenade. La situation critique de la huerta affectée par des facteurs

\footnotetext{
* Email: mariamar@um.es. Dpto. Prehistoria, Arqueología, Ha Antigua, Hª Medieval y CCTTHH. Universidad de Murcia.

** Email: p-h-m@hotmail.com. Universidad de Murcia.
} 
naturels (inondations et sécheresses) et sociaux (corruption des institutions et non-respect des normes) était une réalité depuis les années soixante-dix. La réforme législative des monarques s'acheva au début du XVIe siècle avec la promulgation des ordonnances de l'irrigation pour le royaume de Murcie.

\section{Mots clés}

Irrigation. Murcia. Ordonnances. Rois Catholiques. Les conflits sociaux.

\section{Introducción}

Como bien expusiera A. Black ${ }^{1}$, en el pensamiento político de la Europa bajomedieval -influido por la tradición cívica grecorromana y el pensamiento aristotélico tomista- la función del gobernante, en este caso el rey, era procurar el bien común, el bien de la sociedad. Este solo se podía establecer mediante la ley, y su aplicación fue el objetivo de la monarquía de los Reyes Católicos. La ley legitimaba la autoridad política y las leyes otorgadas por el gobernante prohibían los delitos contra las personas y la propiedad. El proceso legal permitía administrar justicia, o sea reparar los agravios cometidos. En el tema que se analiza ${ }^{2}$, parte de las leyes escritas (ordenanzas) que regulaban el regadío estaban

Antony Black, El pensamiento político en Europa 1250-1450, Cambridge University Press, 1996, pp. 52-55. 2 Desde una perspectiva histórica, los textos normativos completados con los de aplicación del derecho, permiten conocer los problemas existentes en la agricultura intensiva, y sin embargo, para el Medievo hispano, no han sido suficientemente analizados en sí mismos. Vid. Almudayna (equipo-editorial), "Los regadíos hispanos en la Edad Media", en Cuadernos de Investigación Medieval, 10, Madrid, 1992. Cristina SegurA Graí̃o (coord.), Historia de los regadios en España (... a.C-1931), Madrid, 2002. Emilio Olmos Herguedas, "El agua en la norma escrita. Una comparación de ordenanzas bajomedievales castellanas", en Agua y sistemas hidráulicos en la Edad Media, Madrid, 2003. Por la similitud entre el regadío murciano y valenciano, Enric Guinot y María Martínez, "Por una historia conjunta: El Consejo de Hombres Buenos de Murcia y el Tribunal de las Aguas de Valencia", en El Consejo de Hombres Buenos y el Tribunal de las Aguas, Murcia, 2005, pp. 35-43. Enric Guinot, "El gobierno del agua en las huertas medievales mediterráneas: los casos de Valencia y Murcia”, en Espacios de poder y formas sociales en la Edad Media. Estudios dedicados a Ángel Barrios, Universidad de Salamanca, 2007, pp. 99-118; y recientemente J. A. Bonachía Hernando, "El agua en Las Partidas", en Agua y sociedad en la Edad Media hispana, (M ${ }^{\mathrm{a}} \mathrm{I}$. del Val y J.A. Bonachía coord.), Granada, 2012, pp. 14-64. Ma Isabel del VAL VAldivieso: "El agua en los fueros medievales de la corona castellana", en Agua y sociedad en la Edad Media hispana (M I. del Val y J.A. Bonachía, coord.), Granada 2012, pp. 65-94. Para Murcia, Juan ToRres Fontes, Las ordenanzas del regadio murciano en la primera mitad del siglo XIV, Murcia, 1975; "Ordenaciones para la guarda de la Huerta de Murcia (1305-1347) y ordenanzas para la guarda del campo (s. XV)". Miscelánea Medieval Murciana, 12 (1985); María MARTínez: Unas ordenanzas inéditas de la huerta de Murcia durante el reinado de los Reyes Católicos, Ayuntamiento de Murcia, 2006 $\left(1^{\mathrm{a} e d}\right.$.). Desde los años ochenta, bastantes estudios abundan en el conocimiento del regadío peninsular desde sus distintas perspectivas (históricas, arqueológicas, antropológicas, literarias, técnicas, institucionales, lexicográficas, etc.) y planteamientos temáticos. Baste recordar a T.F. GLıcK (Regadio y sociedad en la Valencia medieval, Valencia, 1988) a quien recientemente se le ha homenajeado en Valencia en el Congreso "Regadío, sociedad y territorio", o los nombres de algunos pioneros estudiosos como José Rodríguez Molina (El regadío medieval andaluz, Jaén, 1991) sin mencionar a los especialistas en arqueología agraria, hidráulica o del paisaje en al-Ándalus, ni tampoco las abundantes publicaciones temático-espaciales acerca del agua vinculadas, sobre todo, a las coordinaciones y trabajos de $\mathrm{M}^{\mathrm{a}}$ Isabel del VAL VALDIVIESo (El agua en las ciudades castellanas durante la Edad Media. Fuentes para su estudio, Valladolid, 1998; Usos sociales del agua en las ciudades hispánicas de la Edad Media, Valladolid 2002; Agua y poder en la Castilla bajomedieval. El papel del agua en el ejercicio del poder concejil a fines de la Edad Media, Valladolid, 2003, Vivir del agua en las ciudades medievales, Valladolid, 2006, etc.; Enric Guinot RodríGuEz, "La construcción d'un paisatge medieval irrigat: 
legitimadas por la costumbre (consuetudo o ley no escrita) -y la autoridad de la costumbre o tradición representaba la voluntad de la gente-y se sancionaban por el poder público, la monarquía o/y el concejo. La costumbre se reproducía en norma escrita para adaptarse a las nuevas realidades sociales devenidas de la conquista castellana del emirato hudi, tras la cual Alfonso X promulgaba una serie de disposiciones para conservar el legado del regadío o huerta andalusí. La documentación conservada de la segunda mitad del siglo XIII (fundamental el valioso Repartimiento de la huerta de Murcia publicado por Juan Torres Fontes) ha permitido conocer la realidad del regadío heredado y las transformaciones resultantes del cambio político, social y cultural establecido tras la incorporación a Castilla de la Murcia andalusí ${ }^{3}$. El derecho consuetudinario, que transmitía tradiciones andalusíes, fue regulado por la monarquía a través de disposiciones escritas emitidas durante la época de transición del regadío andalusí al castellano entre las décadas finales del siglo XIII y el primer tercio del siglo XIV. No obstante, los primeros intentos de codificación, las primeras ordenanzas del regadío murciano, los materializaba el concejo en un códice a mediados del siglo $\mathrm{XIV}^{4}$, y durante el siglo XV se fueron legislando puntualmente un conjunto de medidas para la salvaguarda de la huerta. Sobre estas bases y precedentes legislativos dispersos y otros registrados en las actas capitulares del concejo se iniciaría la reforma del regadío en el reinado de los Reyes Católicos.

l'horta de la ciutat de València", en Natura i desenvolupament: el medi ambient a l'Edat Mitjana (Flocel Sabaté, coord.), 2007, pp. 191-200; "El regadío histórico en el mundo mudéjar-morisco", Entre tierra y fe: los musulmanes en el reino cristiano de Valencia (1258-1609), (Norberto Piqueras Sánchez, coord.), 2009, 219-228, "La construcción del paisaje en una huerta feudal: la Séquia de Vila-Real (siglos XIII-XV)", en Hidráulica agraria y sociedad: prácticas técnicas, espacios (Josep Torro y Enric Guinot, coords.), 2012, pp. 103-146; y Carmen TriLlo (Agua, tierra y hombres. La dimensión agrícola del mundo nazarí, Granada, 2004; El agua en Al-Ándalus, Málaga, 2009, etc.). La evolución historiográfica del regadío en María MARTínEz, La cultura del agua en Murcia (siglos $I X-X V$ ), Ed. Editum, Universidad de Murcia, 2013 ( $2^{\mathrm{a}}$ ed.), pp. 17-24. Como ejemplos recientes: Manuel Espinar Moreno y José Manuel Espinar JimÉnEZ, Abastecimiento urbano y regadio en Granada. I. De la Fuente Grande de Alfacar al río Beiro, Granada, 2013; Covadonga Valdaliso Casanova, "Agua y espacio en el discurso historiográfico medieval castellano", en Seminario El agua imaginada en las sociedades ibéricas bajomedievales, Valladolid, 2013.

3 María Martínez, La cultura del agua ..., pp. 34-42: Destáquense para el regadío murciano del siglo XIII los trabajos y documentos publicados por Juan Torres Fontes en esa monografía citados; recientemente, Jorge A. EiroA Rodríguez, "Arqueología de los espacios agrarios andalusíes en el sureste peninsular: nuevas perspectivas desde la periferia", Por una arqueología agraria. Perspectivas de investigación sobre espacios de cultivo en las sociedades medievales hispánicas. Helena Kirchner (Ed.), Oxford, Bar International Series 2062, 2010, pp. 107-121. Relacionado con este tema, una visión de conjunto en Margarita Borx Amorós, "El regadío medieval en España. Época árabe y conquista cristiana", en Hitos históricos de los regadíos españoles, Madrid, 1992, pp. 40-90, y en el ámbito surestino algunos trabajos concretos como los de Jorge Ortuño Molina, "Recursos hídricos y política de aguas en el sureste de la Península Ibérica durante la Baja Edad Media", Miscelánea Medieval Murciana, XXI-XXX (2005-2006), pp.121-151; Manuel de GEA CALATAYUd y otros: "Redes de regadío urbanas y rurales del Bajo Segura en época andalusí. Los casos del Segura y el Chícamo", en Homenaje a T.F. Glick, (septiembre 2014).

4 Sin que se produjera una ruptura con el legado andalusí, el regadío castellano fue reorganizándose a lo largo de la primera mitad del siglo XIV, y a mediados de esta centuria el concejo trató de compilar, adaptar y completar un conjunto de normas tendentes a conservarlo y protegerlo, que se encuentran contenidas en un códice al que Díaz Cassou bautizó (exageradamente) como "Libro del Agua", y que fue parcialmente publicado por ToRRES FonTes, El regadío murciano..., pp. 37-58; “Ordenaciones para la guarda de la Huerta...”, pp. 255-274. 
La rigidez aparente de los preceptos jurídicos se modela cuando se contextualizan, porque más allá del contenido regulador que expresa la normativa sancionada por el poder local, esta ha de interrelacionarse con la evolución político-institucional y socialeconómica de Murcia durante la Baja Edad Media para comprenderlas mejor. En estos como en otros acuerdos reguladores de la vida de una población se expresa la sociedad que las crea, el poder público, y para quien las aplica, la mayoritaria sociedad campesina que aunque habite la ciudad vive de la tierra o la minoría social que explota el espacio agrícola para la extracción de rentas y de acumulación de riqueza. La fuente del derecho sobre la que se organiza la vida en el regadío murciano manifiesta, como es notorio, sus problemas y conflictos socioeconómicos en un tiempo determinado y con acciones precisas, puntuales y vigentes en cada momento, a fin de defender derechos y exigir obligaciones de vecinos y foráneos. Y los conflictos derivados por derechos o intereses contrapuestos y la relajación de obligaciones o la infracción e incumplimiento son el trasunto de los acuerdos adoptados y de las ordenanzas de la huerta.

El objetivo que se propone es diseccionar el proceso legislativo efectuado por los Reyes Católicos para el regadío murciano mediante el establecimiento de unas normas escritas $\mathrm{u}$ ordenanzas generadas en el concejo pero sometidas finalmente a la aprobación de la monarquía. La fijación de la tradición o costumbre en norma escrita garantizaba el conocimiento y cumplimiento de lo que era útil para el bien común de la sociedad. El contenido de las leyes u ordenanzas del regadío permite observar en detalle cuáles eran los problemas más acuciantes que había que resolver para la administración de la huerta (robos de agua, fruta, leña, etc., cultivos dañados por el ganado, talas, salvaguarda de personas, bienes e infraestructura, etc.), sus realidades económicas (extensión de la superficie de riego, intensificación y diversidad agrícola, cambios en el poblamiento y el paisaje, ocupación de tierras por el paso y la estancia de ganado, etc.) y puntuales conflictos sociales derivados de las desigualdades de la propiedad agraria, los intereses contrapuestos entre ganaderos y agricultores y la mala praxis de las autoridades encargadas de la aplicación de las ordenanzas.

Se partía de la necesidad de adaptar las normas escritas preexistentes a la realidad de esta serie de problemas seculares que afectaban al conjunto de la mayoría social que directa o indirectamente vivía de la tierra. Por tanto, la norma escrita perseguía un fin político: erigirse como instrumento de poder y autoridad sobre la sociedad, bien a través del concejo local o de este subordinado al superior y efectivo poder de la soberanía monárquica que lo controlaba. No se trataba de realizar con los estatutos del regadío ningún cambio en la estructura de la propiedad sino de establecer una ley común con la participación en el proyecto legislativo de los distintos grupos sociales afectados por ella: los privilegiados (oligarquía concejil, grandes propietarios, baja nobleza o caballería villana) y los no privilegiados (pequeños y medianos propietarios que se engloban bajo la categoría de "ciudadanos"). Se pretendía con la ley asegurar equilibradamente los usos del regadío ante la realidad de la expansión agropecuaria que desde la segunda mitad del siglo XV se revelaba rotunda: por una parte, el aumento de las tierras de cultivo y la explotación del territorio circundante, generado por la extensión de la red 
hidráulica, que había alcanzado hacia 1480 las 6.000 Has, aproximadamente la superficie que había tenido la huerta andalusí antes de la conquista castellana de mediados del siglo XIII; y por otra, el continuado desarrollo de la ganadería local y trashumante que enfrentaba a los diversos sectores de la sociedad, aunque no exclusivamente se centraba el problema en la oposición agricultura-ganadería, pues grandes propietarios agrícolas eran simultáneamente potentes ganaderos y obtenían riqueza tanto de la producción de cereal como de la lana y la seda, productos de gran demanda comercial en los circuitos comerciales internos y externos.

La necesidad de unas nuevas ordenanzas venía impuesta para poder gestionar -sin detrimento del prioritario aprovechamiento intensivo de los cultivos y de la infraestructura hidráulica- el espacio agrario. La normativa surgía del conocimiento o asesoramiento que los hombres del concejo tenían del regadío, lo que no aseguraba su protección aun cuando la ley fuese razonable y justa para la salvaguarda del conjunto de intereses de la sociedad, pues primaban los particulares y la connivencia en la aplicación y ejecución de las disposiciones sancionadas. Y como la permanencia y obligatoriedad son características de este tipo de corpus de ordenanzas locales 5 , en el caso del regadío, estas leyes municipales tenían como objetivo crear un derecho unificado y actualizado. Una tarea complicada pues los desacuerdos internos respondían a la prevalencia de intereses particulares y a la connivencia entre la autoridad local encargada de velar por el cumplimiento de la norma y los individuos a quienes debía aplicarse. Por consiguiente, realizar unas leyes del regadío era el primer paso para gestionar el fundamento de la economía murciana. Será la naturaleza de las relaciones políticas anudadas en torno a las diferentes condiciones sociales o/y a comunes fuentes de riqueza de la población lo que anularía la efectividad de las leyes establecidas.

Después de las primeras normativas dispuestas por Alfonso X, que inauguran el proceso de regulación y readaptación del regadío andalusí heredado, el concejo siguió tomando acuerdos y disposiciones desde mediados del siglo XIV, aunque no sería hasta el gobierno de los Reyes Católicos cuando la tarea ordenancista tomaba visos de contundencia, exigiendo los monarcas al concejo la revisión, selección y vigencia de los acuerdos y preceptos establecidos desde tiempo atrás para defender el regadío y, consecuentemente, su envío al Consejo Real para valorarlos y enmendarlos si se creía conveniente antes de su promulgación. Una tarea compleja desarrollada a lo largo de 25 años que se demoró por los avatares históricos sucedidos en la corona castellana y por la dificultad y complejidad de consensuar localmente la adaptación de las ordenanzas del regadío antes de someterlas a la revisión y aprobación de la monarquía. Si el concejo urbano había intervenido y sometido a su directa dependencia al concejo rural y a las instituciones de la huerta, el poder local o concejo urbano había quedado finalmente controlado/ moderado por el corregidor, representante de la monarquía en el gobierno local. En consecuencia, la administración municipal de la ciudad y del regadío se subordinaba

Vid. Miguel Ángel Ladero Quesada, “Las ordenanzas locales. Siglos XIII-XVIII”, en La España Medieval, 21, (1998), p. 307. 
a la central a través de los delegados regios. Bajo el proceso ordenancista, vertebrado a través de las instituciones administrativas del estado monárquico de los Reyes Católicos, subyacen situaciones sociales conflictivas y opuestos intereses económicos que retrasaron la reforma legislativa del regadío murciano hasta comienzos del siglo XVI. Por todo ello y pese a la prolijidad derivada de los datos recopilados, resulta obligado en este tipo de trabajo de investigación de base puntualizar tanto la cronología del proceso de reforma del regadío a través de las numerosas ordenanzas y preceptos existentes para el periodo de estudio -y que muestran los cambios y matices de contenido de las mismas-, como los hechos concretos que identifican y pormenorizan los problemas sociales y económicos derivados de la explotación y el uso de la tierra de riego. La información que se expone es igualmente valiosa para acceder al conocimiento del regadío desde una lectura más social, económica y arqueológica, pero en esta oportunidad se ha optado por desentrañar el proceso histórico-jurídico, el contexto y el contenido temático de los textos normativos y cotejarlos con los acontecimientos puntuales con él relacionados, lo que necesariamente completa la óptica legislativa con la socioeconómica. Se trata ahora de un estudio, legislar para administrar el regadío, restringido al ejemplo murciano, que permitiría en otra oportunidad establecer una comparación con la organización y los problemas del regadío existentes en otros ámbitos espaciales, caso del regadío andaluz o valenciano, con el que existieron por razones históricas muchas convergencias políticas, institucionales, sociales y económicas.

\section{Hacia la promulgación de un "corpus" de leyes para el regadío murciano: las "ordenanzas de la huerta" durante el reinado de los Reyes Católicos}

En la Corona de Castilla la monarquía de los Reyes Católicos -asumidos los principios romanistas del poder real- impulsó la tarea reformista legislativa, que fue una característica desde los inicios del reinado. La redacción de leyes generales y homogeneizadoras (ordenanzas generales) así como la revisión y promulgación de ordenamientos u ordenanzas locales fueron dos facetas bien asumidas por el poder regio ${ }^{6}$. En este marco político-jurídico se incardina el proceso de elaboración, codificación y promulgación de las Ordenanzas de la Huerta de Murcia que se analiza a lo largo de prácticamente el gobierno conjunto de los Reyes Católicos.

\footnotetext{
6 El lenguaje utilizado para la reglamentación de la huerta es el de ordenamientos, ordenaciones y ordenanzas, términos aparentemente equivalentes o sinónimos, en el sentido de que todos estos conceptos señalan las disposiciones emanadas de un poder o autoridad superior. En el caso de la ordenación, sería la acción de ordenar por dicha instancia superior (concejo o/y monarquía en el caso que se estudia) y, derivadamente, las ordenanzas dictadas para la reglamentación de algo (en este tema el regadío). Mientras que el ordenamiento también implica, obviamente, la acción de ordenar, pero se refiere a un conjunto de leyes dictadas al mismo tiempo o sobre la misma materia. En cualquier caso, se trata de establecer los hitos en la tarea ordenancista efectuada por el poder local murciano y la monarquía castellana durante la Baja Edad Media.
} 
Junto al análisis del contenido de las ordenanzas del regadío, lo que se quiere subrayar, como analizó Martínez ${ }^{7}$, es la conflictividad interna y la oposición entre unos y otros (ganaderos y agricultores, grandes propietarios o señores frente a pequeños propietarios) en defensa de intereses particulares que tanto alargaron y dificultaron el consenso y final revisión de las normas con que defender y administrar la huerta de Murcia. El cotejo de la normativa teórica contenida en las ordenanzas del regadío con los documentos de aplicación del derecho o susceptibles de ello (quejas, denuncias, protestas, agravios, etc.) que se han exhumado confirman una conflictiva situación en la base de la sociedad y economía murcianas que derivaba del incumplimiento de la ley y se acusaba por factores climáticos naturales ${ }^{8}$. Es más, la codificación del derecho tradicional del regadío murciano está directamente vinculada con una conflictividad social interna que se revela con contundencia desde la segunda mitad del siglo XV por factores diversos e interdependientes de naturaleza política, social y económica.

\subsection{La primera fase de la reforma legislativa del regadio murciano (1479-1495)}

Como se ha apuntado, el proceso de codificación de las leyes del regadío se remontaba a los orígenes del reino castellano de Murcia con las disposiciones alfonsíes, que fueron ampliadas por el concejo murciano a lo largo del siglo XIV con el fin de reorganizar la huerta y el conjunto de la vida en la capital del reino. Una serie de normativas locales que se adaptaban a la realidad de una nueva sociedad feudalizada sobre la que repercutían las decisiones de un poder local oligarquizado que fue eliminando desde mediados del siglo XIV la capacidad decisoria de los propietarios-regantes representados por el concejo de herederos. La pérdida de autonomía de este concejo rural, la subordinación de los cargos y oficios del regadío al concejo capitalino y la existencia de un cúmulo asistemático de normativas obligó durante el siglo XV a seguir legislando de forma puntual y con algunas normas muy concretas para dar solución a los problemas que se presentaban o acusaban. Con frecuencia era necesario aclarar la confusión resultante de la existencia de antiguos y nuevos preceptos que incidían sobre un mismo asunto, por lo que se puntualizaban, completaban, matizaban o derogaban cuando no se creaban para

Unas ordenanzas inéditas..., pp. 28-32.

8 Sequía e inundaciones bien documentadas se alternaban produciendo muertes, carestías, gastos constantes, desabastecimiento, etc.: María MArTínez, La cultura del agua ..., p. 79 y ss.. En 1465, 1466 y 1472 están documentadas inundaciones y en 1473 una sequía que propició rogativas y procesiones para que lloviese. Junto a ello, plagas de langosta en los años 1463-1466 redundaban en los "males externos" del regadío antes del comienzo del reinado de los Reyes Católicos y en la carestía de los productos agrícolas: Belén PIQUERAS García, Fiscalidad real y concejil en el reinado de Enrique IV, Universidad de Cádiz, 1988, pp. 75-77. A principios del siglo XVI, el concejo explicaba a los monarcas las consecuencias de las graves avenidas del río: commo de largos tienpos aca esta çibdad resçibe grandes dannos de las auenidas que de antigo vienen por este rio, derramando por las huertas frutos y esquilmos della, de que se faze tan grand detrimento que apenas se cojen los frutos que en ella ay y commo esta tierra sea esteril y a ella acuden tarde los temporales y commo no tiene otro sustentamiento saluo las huertas. Y aquellas por las auenidas faltan de contino en esta çibdad, ay grandes neçesidades y grandes gastos, asy para el proueymiento della commo para los reparos e obras que se fazen...: AMMU (Archivo Municipal de Murcia), Leg. 4376, nº 86. A.Doc. 14. 
adaptarlos y ajustarlos a los cambios socioeconómicos que se fueron produciendo a lo largo de la centuria. Un punto de inflexión en la evolución de las leyes del regadío lo marca desde mediados del siglo XV el despegue económico que propició la expansión de la ganadería y la extensión del área huertana. Las tierras de riego se habían ampliado y se pusieron en cultivo otras en su periferia, que se intercalaban como una zona intermedia entre el regadío y el secano propiamente dichos. La introducción de nuevos cultivos como el pastel, la morera y la caña de azúcar y el desarrollo de la ganadería produjeron transformaciones en la agricultura intensiva de subsistencia, en la industria textil y en la reactivación comercial de Murcia, pues la lana y la seda eran materias primas demandadas en los circuitos del tráfico internacional. Empero, la producción de trigo primaría en la agricultura intensiva, aunque sintomáticamente se mantuviese deficitaria para cubrir las necesidades de una población en crecimiento que rebasaría los 10.000 habitantes ya entrado el siglo XVI.

En este contexto en que la autoridad del reino estaba de facto en manos del adelantado Pedro Fajardo, la monarquía impuso su soberanía e impulsó el proceso de codificación de las ordenanzas del regadío murciano. Por una parte, la función legislativa y reformista de los Reyes quedaba enseguida plasmada en las Cortes de Toledo de 1480, expresión del autoritarismo regio, que pretendió homogeneizar la legislación para limitar los particularismos locales. La unificación legislativa en el marco legal de la Corona de Castilla es el telón de fondo sobre el que hay que proyectar la organización y revisión de las leyes del regadío murciano. Por otra parte, la empresa bélica contra Granada - uno de cuyos frentes se situaba desde 1482 en la frontera murciana- es otra de las coordenadas que ayudan a explicar la inestable situación del regadío murciano durante los años ochenta y noventa, y en consecuencia la necesidad de revisar, actualizar y promulgar unas nuevas ordenanzas que se articulan en el marco de la política económica de los Reyes Católicos destinada a la homogeneización jurídica de las actividades laborales más pujantes, como se conseguiría para la industria textil con la promulgación de ordenanzas generales a finales de la centuria.

Cuando se reinstaura la autoridad monárquica en Murcia con los Reyes Católicos, la desorganización del regadío plasmaba las secuelas de la crisis sucesoria, la inestabilidad política y económica de los años finales del reinado de Enrique IV y los males endémicos como las talas de arbolado, robos y daños en los cultivos y productos de la huerta (cereales, viñas, cebada verde y "hierbas"). Estos perjuicios procedían de gentes y animales con "poco temor a la justicia", pues actuaban en ella como si de una tierra de nadie se tratara. El regadío se reforzó institucionalmente con la novedad del nombramiento de un "sobreguarda", que recayó en el conocido regidor Sancho de Dávalos

\footnotetext{
$9 \quad \mathrm{M}^{\mathrm{a}}$ de los LLanos Martínez Carrillo, Los paisajes fluviales y sus hombres en la Baja Edad Media. El discurrir del Segura, Universidad de Murcia, 1997, pp. 199-200: Según la autora era "sobreguarda" porque "englobaba tanto a los ganados de las carnicerías como a los ganados particulares, en tanto que la guardia ordinaria de la huerta solo afectaba a los segundos". Desde el primer tercio del siglo XV se mencionan ordenanzas de la "sobreguarda" de la huerta.
} 
en los años setenta ${ }^{10}$, cuya competencia se situó por encima de la función del control y vigilancia que tenían los guardianes y arrendadores. Junto a esta mayor protección institucional, el incremento de las multas fue otra de las cuestiones modificadas para disuadir a quienes conculcaban las reglas del regadío.

El nombramiento de sobreguarda del regidor Sancho Dávalos se acompañaba de algunas enmiendas a la normativa vigente, que están sin datar, pero posiblemente sean de principios del reinado de los Reyes Católicos, aunque de momento no se puede precisar la fecha, aunque sí que en 1479 ya existían unas ordenanzas de la huerta ${ }^{11}$. Según se corregía en el texto sin data, las multas por la estancia y el daño ocasionado por el ganado aumentaban a medio florín si el perjuicio se producía de día y el doble si se cometía de noche. En caso de ser ganado vacuno se doblaban estas multas, respectivamente. Por los asnos se pagarían 5 mrs. de día y 10 de noche cuando produjesen algún daño, igual que si se trataba de ganado lanar, cabrío y porcino. La siega fraudulenta de cereal o recolección de legumbres, hierba, cebada verde y alfalfa se penalizaba con 50 mrs., y el doble si se realizaba de noche. Tampoco se permitía segar las "hierbas" de los linderos de tierras que no eran propias, ni poner las bestias en ellos ni cerca de los cultivos o barbechos. La entrada en grandes fincas o "reales cerrados", en realidad una gran propiedad con casa y huerta propia, se multaba con $200 \mathrm{mrs}$. si se hacía de día y con el doble de noche si se trataba de un vecino, mientras que los foráneos también debían cumplir prisión de 30 días.

Además de estas cláusulas que pudieran corresponder a las ordenanzas de 1479, en otro texto de ese año se indicaba la relación de una serie de documentos concejiles, entre otros "çiertas ordenanças para la guarda de la huerta". En ese mismo índice se daba cuenta de la existencia de una reglamentación complementaria referente al arrendamiento de la "tabla" o fondo tributario-crediticio para la financiación y mantenimiento de la red de riego ${ }^{12}$, algunos convenios con particulares acerca de modificaciones de cultivos (parras y árboles) en sus tierras, una ordenanza acerca de quienes destruían las boqueras de las acequias y otras normas referidas, en concreto, al indebido uso del agua procedente del río Sangonera que hacían los regantes del señorío de Librilla, así como a la tradicional prohibición de regar haciendo rafas o pequeñas presas, salvo que se demostrase que se venían realizando desde cincuenta

\footnotetext{
10 No se registra la fecha del nombramiento del regidor Sancho Dávalos como sobreguarda, aunque en el mismo documento se incluyen algunas ordenanzas y se precisan otras referidas sobre todo al incremento de las multas para proteger el regadío. AMMU, Leg. 4276, n 63, 2 ff. Vid. A. Doc. n 1: "Sepan todos que por quanto el conçejo, regidores, caualleros, escuderos, ofiçiales e ommes buenos de la muy noble çibdad de Murçia han seydo enformados e les han seydo dados muchas quexas de muchas talas e males e dannos que se han fecho e fazen de cada dia en los panes e vinnas e alcaçeres e yeruas e en otros esquilmos de la huerta desta çibdad, asy por ommes commo por bueyes e vacas e ganados e otros bestiares, auiendo poco temor de la justiçia e de las penas acerca dello puestas e ordenadas, que han encomendado e encargado la sobreguarda de la dicha huerta fasta ser conplido el arrendamiento de los guardianes deste presente anno, porque se pongan en ello algund castigo e escarmiento e se escriuieren los dichos dannos, a Sancho de Daualos...".

11 A finales de 1478, el concejo murciano había encargado a una comisión que enmendara y "templara" las ordenanzas de la huerta: Ma de los LLanos Martínez Carrillo, Los paisajes fluviales..., p. 200.

12 Ma de los Llanos Martínez Carrillo, Los paisajes fluviales..., pp. 44-46.
} 
años atrás y que, además, los regantes habían pagado las derramas para la reparación y mantenimiento del Azud mayor ${ }^{13}$. Igualmente, se prohibía, otra vez más, que el ganado no anduviese ni estuviese en la huerta, elevándose la multa a nada menos que 10.000 mrs., y se impedía asimismo que el ganado permaneciese en Villora, una alquería al sur de la ciudad en las proximidades de la sierra. Se recordaba igualmente que los guardianes del regadío serían solo aquellos que el concejo nombrase; se otorgaban ordenanzas específicas para la zona de Sangonera, en la periferia del regadío de la zona sur, y se arrendaban las multas correspondientes a la Hermandad, institución creada por los monarcas para la salvaguarda del orden público en los espacios más vulnerables como caminos y despoblados ${ }^{14}$.

La reglamentación del regadío murciano en 1479 fue previa a la apertura del frente oriental para las campañas granadinas que, desde los años ochenta, absorbía hombres y dinero, lo que unido a los factores endógenos de diverso signo - naturales, políticos y sociales- abría una etapa de desequilibrio y fisura institucional que se manifestaba en un continuo allanamiento, dejación y violación de las leyes del regadío. La guerra contra Granada y la oposición de intereses agrícolas y ganaderos habían convertido la huerta en una tierra donde la ley no se asumía o se contravenía impunemente con estrategias y violencias, pese a que la monarquía había intervenido a la oligarquía concejil con la imposición del corregidor a fin de arbitrar con su voto de calidad la toma de decisiones de los miembros de un concejo definitivamente oligarquizado y patrimonializado.

Entre los muchos ejemplos de abusos, contravenciones y desacatos que podrían exponerse para comprender la crisis del regadío, se han seleccionado algunos inéditos de mediados de los ochenta, mientras que otros textos, cuya datación no consta, también son de esos años, pues coinciden con el tipo de escritura de los que sí están fechados. Así, en 1484, Bartolomé Vidal presentaba una queja al concejo por el perjuicio que en el riego de sus tierras le había ocasionado la construcción de un canal en la Puerta de las "Menoretas" (o monjas clarisas), al igual que diez años después Isabel de Valenzuela solicitaba al concejo que no se le expropiaran las cinco tahúllas de tierra que tenía en esa zona al norte de la ciudad ${ }^{15}$. Otras muchas denuncias y peticiones recibía el concejo por cuestiones que afectaban a pequeños propietarios del regadío murciano: en 1485, Antón Sánchez denunciaba a Juan Hidalgo porque este pretendía quitarle ocho tahúllas de tierra de riego ${ }^{16}$. Por estos mismos años, cuatro propietarios-ganaderos de tierras en Monteagudo y Casillas, en el noreste de la huerta, reclamaban el antiguo

\footnotetext{
13 Por "hacer rafa" se revocaba el permiso de riego a un tal Alonso García y se confirmaba que nadie regase con rafa sin expreso permiso concejil: AMMU, Leg. 4291, $\mathrm{n}^{\circ} 18,13$ ff. Vid. A. Doc. $\mathrm{n}^{\circ} 2$.

14 AMMU, Leg. 4291, nº 18, 13 ff. Vid. A. Doc no 2.

15 Se trataba de "panificar" la denominada "Laguna del Bovar" mediante un azarbe o canal de avenamiento: AMMU, Leg. 4280, n 65, 1 f. Vid. A. Doc. 6. AMMU, Leg. 4287, n 11, 1 f. Vid. A. Doc. $n^{\circ}$ 9. María MartíneZ, La cultura del agua ...: 75-76: El Bovar era una laguna situada al norte de la ciudad, próxima al actual convento de Las Claras, que desde mediados del siglo XV se comenzó a desecar para cultivo de cereal y alfalfa, aunque los vertidos en ella de las curtidurías la convertirían en un foco insalubre; y $\mathrm{M}^{\mathrm{a}}$ de los LLanos Martínez Carrillo, Los paisajes fluviales..., pp. 137-143.

16 AMMU, Leg. 4281, nº 6, 1 f. Vid. A. Doc. $n^{\circ} 7$.
} 
derecho consuetudinario que permitía llevar a estas alquerías su ganado para pastar y dormir con él fuera de los corrales "en aquellos lugares e prados mas desenbargados guardando de no hazer danno ninguno en los panes nin otros esquilmos" ${ }^{17}$. La intromisión del ganado en el regadío es una de las cuestiones más reguladas en la legislación sobre la huerta que trataba de delimitar los espacios de cultivo y los permitidos para el pasto del ganado. Desde principios del siglo XIV se aseguraba el aprovisionamiento cárnico de los murcianos y para ello se permitía que los rebaños cuya carne se pondría a la venta en las distintas tablas (o mostradores donde específicamente se vendía cada tipo de carne) de las carnicerías murcianas pudiesen estar dentro del regadío, si bien se establecía el número de cabezas permitidas (entre 50 y 100 según los años). Hacia los años ochenta del siglo XV, el carnicero Pedro Avilés solicitaba al concejo que se le permitiese tener en el regadío $200 \operatorname{cerdos}^{18}$. Solicitud vinculada a la tajante ordenanza que obligaba a cualquier ganado porcino a salir del regadío, pues solo se permitía que los cerdos para consumo doméstico o las piaras para aprovisionamiento de las carnicerías permanecieran en el secano, debido al aumento de la cabaña porcina ${ }^{19}$. La cabaña ganadera local o/trashumante había aumentado considerablemente a finales del cuatrocientos y junto con el ganado destinado al abastecimiento de las carnicerías había ocupado gran parte del regadío y devoraba los rastrojos, esquilmos, barbechos $\mathrm{y}$ viñas ${ }^{20}$. Los animales reservados para el abasto de carne se concentraban al norte del río, en el sector comprendido entre el camino de Molina y la frontera aragonesa con Orihuela. Al soslayo del pasto de este ganado cárnico se encubrían otros ganados destinados al comercio con Aragón que herbajaban ilegalmente en el regadío murciano. Ganado para las carnicerías que pastaba entre la zona de riego y los raigueros o vertientes y que hasta mediados del siglo XV se trasladaba por la noche a los corrales de la ciudad. Sin embargo, a partir de entonces se construyeron corrales en los raigueros (fuera del regadío propiamente dicho donde encerrar de noche el ganado) y en todo el conjunto de la huerta ${ }^{21}$. El objetivo era que ni siquiera el ganado local para las carnicerías permaneciese de noche suelto y proteger así al máximo las tierras de cultivo. Otro problema central del regadío era la regulación del caudal del agua que entraba en las acequias para regar los diferentes sectores de la huerta. Desde 1479 se había obligado a colocar boqueras en las acequias, con el fin de derivar desde ellas el agua de esos

\footnotetext{
17 Solicitaban al concejo la devolución de las prendas requisadas por los alcaldes de la huerta, pues alegaban que no tenían información de la nueva ordenanza que obligaba a encerrar el ganado de noche en los corrales y se comprometían a cumplir las nuevas ordenanzas: AMMU, Leg. 4287, nº 83, s.f., 1 f. Vid. A. Doc. 3. 18 "... yo tengo para la prouisyon desta çibdad dozientas cabeças de puercos, los quales continuamente tengo de matar e porque me seria grand trabajo sy los oviese de tener fuera de la huerta e porque los annos pasados se a fecho, suplico a vuestra merçed me de liçençia para que los pueda tener por la huerta con las condiçiones del ganado de las carneçerias": AMMU, Leg. 4287, $\mathrm{n}^{\circ} 42,1 \mathrm{f}$. Vid. A. Doc. $\mathrm{n}^{\circ} 15$.

$19 \mathrm{M}^{\mathrm{a}}$ de los LLanos Martínez Carrillo, Los paisajes fluviales.... pp. 210-211.

20 Información detallada en María MartíneZ, La industria del vestido en Murcia (ss. XIII-XV), Murcia 1988, pp. 20-23: en 1488 la cabaña ovina se cifraba en 227.500 cabezas, una cifra excepcional que se explicaría por el abastecimiento para la guerra de Granada, aunque existen otros muchos datos que confirman el incremento de la ganadería local y trashumante.

${ }_{21} \mathrm{M}^{\mathrm{a}}$ de los LLanos Martínez Carrillo, Los paisajes fluviales..., pp. 201-205.
} 
canales de riego hacia otros lugares. De ello se quejaba Diego Riquelme, procurador y representante de los propietarios-regantes de la acequia de Turbedal, al concejo y solicitaba la revocación de la ordenanza justificando que la citada acequia era diferente porque se nutría del agua del Sangonera ${ }^{22}$. Y también los problemas por el reparto del agua o tandas que correspondían al riego de las tierras fueron igualmente reiterativos, máxime cuando la huerta se había extendido hacia el sur en ambas márgenes del río y algunos propietarios se negaban a compartir su agua, como exponía un propietario de "Alavrache" (Larache) ${ }^{23}$ en la zona del noreste, donde predominaban los almarjales.

Junto a los ejemplos documentados que expresan tan solo una muestra, pequeña pero real, de los problemas de la huerta, podrían añadirse otros muchos ${ }^{24}$. Vinculados con los hechos concretos, la documentación inédita de carácter normativo que se ha encontrado en diversos legajos del Archivo Municipal de Murcia permite ampliar el proceso ordenancista del regadío murciano durante el reinado de los Reyes Católicos, lo que explicaría las situaciones reales de los casos documentados, los conflictos sociales surgidos en el aprovechamiento agrícola y ganadero del espacio de riego y el desinterés en la aplicación de las leyes de la huerta. Aunque tampoco se pueda afirmar la fecha precisa de algunos de estos documentos normativos inéditos que contienen -en borrador o fragmento- algunas ordenanzas, sí se consideran, no obstante, muy significativos para poder completar la información hasta hoy editada y establecer la continuidad en las fases del proceso de codificación de las leyes efectuado para el regadío murciano a fines de la Edad Media y clarificar así la evolución de los problemas que le afectaron como consecuencia de los cambios sociales y económicos señalados.

Los años ochenta parece que fueron caóticos en la organización y administración de la huerta, como demuestra el hecho de reiterar la vigencia de ordenanzas que se contravenían constantemente. Al respecto, las de 1486, datadas por García Soriano ${ }^{25}$, muestran una coyuntura de desprotección acusada, pues además el concejo recordaba

22 “... a notiçia mia es venido que vuestras merçedes mandan poner acoda en las boqueras de todas las açequias, haziendo en la boquera una manera de ventana para que no pueda tomar mas agua de aquella que le pertenesçe.... Y sennores, la dicha açequia de Turbedal no es de la condiçion de las otras porque hordenariamente los mas de los annos vienen aguaduchos de Sangonera y envisten la dicha açequia de Turbedal fasta ensima de los quixeros; y sy la tal boquera hallase tan estrechamente puesta no seria mucho que cada vn anno la dicha açequia la ouiesemos de hazer de nueuo. Porque suplico a vuestras merçedes la dicha boquera la manden ver y asy vista hagan aquello que fuese justiçia, dandonos el agua que nos pertenesçe y dexandonos nuestra boquera desenbargada para que los aguaduchos puedan entrar y salir desenbargadamente”: AMMU, Leg. 4287, n 103, 1 f. Vid. A. Doc. nº 14.

23 AMMU. Leg. 4290, $\mathrm{n}^{\circ}$ 65. El propietario, en una carta sin data, pero correspondiente al reinado de los Reyes Católicos, justificaba su negativa a repartir el agua de la tanda correspondiente a este sector de la huerta con un tal Lorenzo, que solamente tenía tres tahúllas, máxime cuando con el agua de la tanda que debía regar cien tahúllas "son marjal las noventa poco mas o menos", es decir tierras encharcadas y pantanosas.

24 Otro muchos ejemplos en $\mathrm{M}^{\mathrm{a}}$ de los LLanos Martínez Carrillo, Los paisajes fluviales..., y en las Actas Capitulares del concejo.

25 Las ordenanzas fechadas por García Soriano en 1486 son de 1488, aprobadas tras la venida a Murcia de los Reyes Católicos: AMMU., AC. 1488-89, ff. 70 R.-72 v. Cit. Por María Martínez, Unas ordenanzas inéditas..., pp. 34-35. Las últimas ordenanzas del regadío que constan databan de 1479. 
a la justicia huertana que juzgase de acuerdo a las ordenanzas e instaba a los jueces a "tener consigo" la legislación y aplicarla correctamente ${ }^{26}$. Otras muchas noticias a partir de los años ochenta, además de las ya expuestas, coadyuvan en la desprotección del regadío y de sus propietarios, especialmente por la falta de recursos en el servicio de vigilancia, cuando la población contribuía militar y económicamente a la guerra de Granada. En consecuencia, se arbitró como refuerzo de vigilancia que, cada seis meses, un regidor y jurado concejiles inspeccionasen las acequias y denunciaran las negligencias de los alcaldes, sobreacequieros ${ }^{27}$ y guardianes de la huerta. Junto a ellos, reos y presos reconvertidos en guardianes del regadío fueron obligados por el concejo murciano a realizar este servicio público, que conllevaba la redención de penas y delitos ${ }^{28}$.

Pese a todo, la afamada tradición de las ordenanzas del regadío murciano, que habían conservado la esencia del reparto del agua de origen andalusí, fue reconocida por las nuevas poblaciones andaluzas recién incorporadas a Castilla, como Antequera, Vera y Loja, que solicitaba al concejo de Murcia en 1493 el envío de un traslado de dichas normas: "commo por ser esta çibdad nuevamente poblada esta en necesidad de hordenanças buenas de las aguas e riego de las heredades; e porque avemos sabido que las hordenanças desa çibdad çerca desto son las mejores destos reynos, acordamos de escreuir carta" ${ }^{\prime 29}$.

\subsection{Las ordenanzas "perdidas" de 1495}

Con la finalización de la empresa granadina en 1492 se abría en firme la labor ordenancista de la monarquía para revisar y establecer unas nuevas ordenanzas consensuadas entre los representantes de la sociedad política: el bloque ciudadano, el concejo y el corregidor, representante de la monarquía que en última instancia debía aprobarlas y promulgarlas. Esta segunda fase del proceso de codificación de las leyes del regadío se iniciaba en 1495 a instancia de los Reyes, quienes obligaban a elaborar unas nuevas ordenanzas de la huerta ${ }^{30}$ para que, debidamente aplicadas, se acabase con la delincuencia, violencia e impunidad existentes. La carta de los monarcas expresaba, resumida, la insostenible situación del regadío murciano y la urgencia de crear y aplicar unas nuevas ordenanzas para remediarla. La ausencia, abandono e incumplimiento de las normativas

\footnotetext{
26 María MARTínez, Unas ordenanzas inéditas..., p. 38.

27 Resulta interesante constatar la exigencia de mantener caballo y armas para acceder al cargo de alcalde de la huerta y de sobreacequiero, lo que demuestra la promoción social sobre todo de estos últimos: $\mathrm{M}^{\mathrm{a}}$ de los LLanos Martínez Carrillo, Los paisajes fluviales..., p. 217.

28 María Martínez, Unas ordenanzas inéditas..., pp. 38 y 66-67, notas 52, 53 y 60.

29 AMMU, Leg. 4281, $\mathrm{n}^{\circ}$ 57. Vid. A. Doc. $\mathrm{n}^{\circ}$ 8. Vid. Miguel JimÉnez Pueras, Los regadíos tradicionales del territorio de Loja. Historia de unos paisajes agrarios de origen medieval, Fundación Ibn al-Jatib de Estudios y cooperación, Motril, 2007.

30 El 6 de junio de 1495 se presentaba en el concejo murciano la carta enviadas por los reyes, en que ordenaban "al dicho sennor corregidor se junte con los regidores e jurados de la dicha çibdad e con otras personas e fagan hordenanças para la guarda de la huerta...". Y entre tanto, "el dicho sennor corregidor tenga forma commo la dicha huerta se guarde”: María MARTínez, Unas ordenanzas inéditas..., p. 61.
} 
amparaban la impunidad de los robos de agua y fruta y la estancia del ganado en la huerta, con las consiguientes violencias sociales derivadas. Pero, sobre todo, la connivencia de la justicia de la huerta y los infractores, con quienes mantenían relaciones sociales, familiares o de amistad, y la falta de competencia judicial del corregidor en el regadío habían arrostrado hacia un clima de anarquía que no podía continuar ${ }^{31}$.

La señorialización del regadío y la expansión de la ganadería constituyeron dos factores complementarios que llevaron al extremo los problemas de la huerta, aunque conviene recordar que muchos ganaderos eran también grandes heredados que tenían intereses agrícolas. La oligarquización del regimiento se había extendido a las autoridades del regadío, pues los alcaldes de la huerta eran elegidos de entre los regidores del concejo. Junto a esta vinculación institucionalizada de intereses, las corruptelas en la vigilancia y la ineficacia de la ejecución de las penas por los delitos cometidos ponían en serio peligro el sostenimiento de la plataforma económica de la ciudad. Se pretendía crear, mantener en vigor y bien adaptado un corpus jurídico-administrativo de la huerta que, revisado y aceptado por las tres fuerzas representativas de la sociedad murciana (concejo, ciudadanos y corregidor), fuese sancionado finalmente por la monarquía. Dicho de otro modo, las iniciales ordenanzas locales se convertirían en reales y, desde las tradiciones ordenancistas precedentes, se creaba el nuevo derecho del regadío con que se iniciaría la Edad Moderna.

Sin embargo, este proceso, que comenzaba sin solución de continuidad en 1495, fue largo debido a la dinámica actividad de la Corona, implicada en una compleja política exterior. Tan solo dos meses después de la llegada de la carta de los monarcas, en agosto de 1495, el concejo murciano ya había enviado a los Reyes las nuevas ordenanzas del regadío que no se han conservado ${ }^{32}$, salvo que sean, como se sugiere, las registradas

\footnotetext{
31 “... que a cabsa de esa dicha çibdad no tener tales hordenanças por donde se administrase e rija la governaçion de ella, en muchos regadios e huertas e señorios de la dicha çibdad e de los vezinos e moradores della se hazen muy grandes exsarutos robos e fuerças, de que muchas vezes se siguen muertes de onbres e otros dannos, los quales no se pueden remediar ni castygar por no tener las dicha hordenanças, de manera que tanbien entren a paçer e cortar e comer las viñas e arboledas e otras cosas el que no tiene ninguna feredad ni otra cosa como el dueño de ellas, porque no tyenen pena laguna para no lo hazer se sy alguna tyene diz que es tan liuiana e diz e diz que esecutase tan pocas vezes que de dia e de noche continuamente se hazen los dichos robos e hurtos e daños en las dichas heredades e paçen con bestias e ganados las viñas e arvoledas e sotos e moreras en que se cria la seda...; e asymismo diz que hurtan el agua de las açequias con que se riegan los panes. E que sobre ello a acaesçido muertes de omes e otros dañon porque los corregidores de la dicha çibdad diz que no entienden en los tales casos, porque los juezes ordinarios de la dicha çibdad lo juzgan e determinan e que las mas de las veces çesan de hazer justiçia, asy porque son sus parientes e amigos como por parçialidades que ellos tiene...": Antonio Gomariz MARín, Documentos Reyes Católicos (1492-1504), Real Academia Alfonso X, Murcia, pp. 304-305. Cit. por María MARTínez, La cultura del agua ...: 106.

32 "los dichos sennores conçejo vieron e aprouaron las hordenanzas que estauan apuntadas por los diputados que la çibdad nonbro. Fechas e mejorando en algunas dellas e enmedando las que vieron que deven llevar e mandar, las quales son del tenor siguiente. Aqui entran las hordenanças", pero no se copian en el Acta, por lo que más aún permite colegir que sean las que se comentan a continuación: AMMU. AC. 1495-1496, 1495-VIII-3, f. 19 r.-v.: Cit. Por María Martínez, Unas ordenanzas inéditas ..., p. 62, nota 30
} 
en tres folios, sin data, a modo de borrador, que se adjuntan en apéndice ${ }^{33}$. Normas que regulaban los asuntos más problemáticos en esos momentos, tales como:

- Se prohibía cambiar de sitio los mojones ("hitas") que delimitaban los sectores dentro del regadío y del secano, bajo multa de 600 mrs., al igual que modificar los márgenes que deslindaban las propiedades, penalizado con $150 \mathrm{mrs}$. Cláusula que demuestra la apropiación de tierras comunales o particulares en la huerta y su periferia.

- Se disponían medidas para la recaudación del diezmo de la hoja de morera ${ }^{34}$, base de la industria de la seda, de la que vivían "la mayor parte de los vecinos"35.

- Obligación de los denunciados - por cualquier infracción de la normativa vigente- a comparecer ante el tribunal competente (alcalde/s de la huerta) en materia del regadío.

- Obligación de los propietarios a construir puentes por encima de las acequias que cruzaban por caminos públicos, para evitar (como se había establecido desde el siglo XIV) que se encharcasen ("sonriego"). Y también se obligaba a los sobreacequieros a informar a los procuradores o representantes de las acequias -o en su defecto a cuatro propietarios de las mismas- o de brazales para que construyesen (de cal y ladrillo) los puentes en un plazo máximo de 30 días. En caso contrario se les juzgaría sin "los oyr ni çitar”, pues la justicia de la huerta se basaba en un procedimiento oral, eficaz, rápido y expeditivo ${ }^{36}$.

- Penalización a quien comprara leña, fruta y hierba procedentes del robo efectuado por los esclavos (negros o blancos) de las haciendas de sus amos o de cualquier otro propietario. La servidumbre existía en las grandes propiedades del regadío, cuya mano de obra era valiosa y delinquían como posible medida de subsistencia.

\footnotetext{
33 Aunque por el contenido de las disposiciones no resulta fácil precisar la datación hay dos hechos que podrían demostrar que son, siquiera en parte, las de 1495: uno la aparición en ellas del pago del diezmo de las hojas de moreras y, otro, y sobre todo, que en una cláusula se insta además de a los guardas de la huerta a "los juramentados", un cuerpo de "policía" rural de base popular registrado por primera vez en $1490 \mathrm{y}$, posteriormente, en el borrador de otras ordenanzas datadas por MARTíNEZ en 1502: Unas ordenanzas inéditas..., 32. AMMU, Leg. 4287, nº 67 bis, 3 ff. Vid. A. Doc. $\mathrm{n}^{\circ} 10$.

34 Los diezmeros debían comunicarlo al concejo para que este lo pregonase y los dueños de las moreras estuviesen disponibles. Para evitar la ausencia de los dueños (por causa de enfermedad, ausencia o fallecimiento y por consiguiente no poder cobrarles el diezmo a ellos o sus viudas), se nombraba anualmente a una "persona buena que tenga sabiduría", para acompañar a los diezmeros en representación de los propietarios que no pudiesen estar presentes. Resulta destacable el hecho de que el regadío se dividía en "cuartos" o distritos territoriales que hacían más eficaz no sólo el reparto del agua sino también el de las contribuciones, como en esta norma se aclara.

35 María MARTíNez, "El arte de la seda en la Murcia medieval: tradición islámica e innovación intercultural", en Castilla y el mundo feudal. Homenaje al profesor Julio Valdeón, II, Valladolid, 2009, pp. 211-236.

36 Vid. María Martínez: "Vigencia de una institución medieval: el Consejo de Hombres Buenos de Murcia", en Mvrgetana, 112 (2005), pp. 21-68; "El poder y la justicia del agua en la Murcia medieval: el Consejo de Hombres Buenos". Cuadernos de Historia de España, 85-86 (2011-2012), pp. 459-466.
} 
- Fijación del jornal de la trilla con yegua en un real por día. La mano de obra campesina a jornal era abundante en la explotación de las grandes propiedades del regadío, aunque se tarifaba el salario mínimo para evitar abusos de los señores.

- Multas que tarifaban los perjuicios ocasionados en el regadío por personas y animales durante la noche.

- Interrogatorios efectuados por los guardianes y "juramentados" ${ }^{37}$ de la huerta a quienes llevasen fruta, leña o hierbas, con mayor motivo si sospechasen que eran robadas. Esta norma se completaba fijando el horario de entrada con fruta en la ciudad: en verano hasta las diez y en invierno hasta las nueve, como tampoco se podía entrar en ella antes del amanecer. El empobrecimiento de la base social acarreado por la guerra de Granada explicaría el incremento de hurtos y robos para la supervivencia.

- Facultades otorgadas a los propietarios del regadío (o a sus labradores o mozos) para retener y prendar a hombres, mujeres o ganado que sorprendiesen dentro de sus tierras.

- Competencias para que guardas, propietarios, labradores, mozos o cualquier hombre bueno, vecino o propietario, que viese a personas o bestias haciendo daño en el regadío, lo denunciaran y cobraran, por la infracción denunciada, la parte de la multa correspondiente a la acusación. La estructura inicialmente minifundista del regadío castellano disminuía a favor de las grandes propiedades $\mathrm{y}$, paralelamente, aumentaban los jornaleros y braceros compuestos por hombres, mujeres, jóvenes y esclavos que trabajaban las tierras de otros.

- Conmutación de la multa pecuniaria por diez días en la cárcel a quienes no pudiesen responder económicamente por la falta o delito cometidos.

- Obligación de los alcaldes, guardas y arrendadores de la huerta a informar a los propietarios del daño que personas o ganados hiciesen en sus tierras, con el fin de que los pudieran denunciar en el plazo de tres días y percibir así la parte correspondiente de la multa. Se concretaba el procedimiento a seguir en caso de infracción de las normas establecidas.

- Prohibición a los guardianes del regadío de "coger ni tomar ninguna fruta ni otras cosas ningunas de lo ageno ni de lo traer de lo suyo".

- Que los propietarios de tierras situadas en las alquerías "fuera de las acequias de la huerta" pusiesen sus propios guardianes, con la condición de que la administración de justicia se reservase al corregidor, como exclusiva autoridad, para imponer el control sobre la desestabilización social y económica existente en un regadío que había ampliado su superficie y poblamiento por el área periférica.

\footnotetext{
$37 \mathrm{M}^{\mathrm{a}}$ de los Llanos Martínez Carrillo, Los paisajes fluviales..., p. 202: En 1490 se menciona por vez primera la existencia de juramentados o cuadrillas vecinales para vigilar la huerta, que eran renovados trimestralmente.
} 
La vigilancia de las tierras que rodeaban el regadío tradicional ("cuerpo de la huerta") quedaba a merced de sus propietarios.

- Fijación de las multas a los ganados que ocasionasen daños en la red de riego: ganado mayor un real por cabeza, puercos medio real por cabeza y ganado menudo diez mrs. por cabeza.

- Fijación del salario del entregador en la décima parte de las multas que ejecutase. Esta figura, que desde el siglo XIV estaba institucionalizada, era a finales del siglo $\mathrm{XV}$ nombrada por el corregidor y los alcaldes de la huerta "a contentamiento de la çibdad”, para ejecutar en el regadío lo que aquellos dispusiesen. Se restablecía así una cierta representación y participación popular en la protección jurídica del regadío.

- Se reiteraba la tradicional ordenanza del siglo XIV que prohibía dañar el puente mayor y los puentes menores del regadío con ningún tipo de instrumento (teja, hierro, cuchillo, "destral" o hacha pequeña, azada, etc.). Igualmente permanecía en vigor la prohibición de robar o extraer piedras de balsas o de lugares ajenos prescritos en las normativas del trescientos ${ }^{38}$. La salvaguarda de la infraestructura hidráulica cobraba relieve en coyunturas de deterioro social.

- Los perjuicios producidos por personas o ganado en el regadío como en el secano debían denunciarse por cualquier persona en el plazo de 20 días.

Finalmente, se remataba que nadie, sin excepción (caballero u otras personas de cualquier estado, condición, preeminencia o dignidad), quedase exento del cumplimiento de la normativa que regulaba la huerta tradicional (la de dentro de las acequias ${ }^{39}$ ), ahora con medidas más precisas y contundentes para defenderla de los hurtos y robos que realizaban gentes empobrecidas y de las redes del clientelismo institucional, representado en los desmanes y corruptelas de jueces, arrendadores y guardianes.

El corregidor era quien, como delegado de los monarcas en la ciudad, debería poner orden en la desestabilización del regadío ante la ineficacia de la oligarquía concejil. Para ello se le otorgaban facultades explícitas en la vigilancia de la huerta y en el control de la administración de la justicia en el mismo. Y con estas ordenanzas que, repetimos, bien pudieran ser, siquiera en parte, las que se enviaron en 1495 a los Reyes, la protección del regadío pretendía asegurarse.

38 Juan Torres Fontes, El regadío murciano..., p. 43.

$39 \mathrm{M}^{\mathrm{a}}$ de los Llanos Martínez Carrillo, Los paisajes fluviales..., pp. 63 y 149. El "cuerpo de la huerta" o "huerta vieja" lo delimitaban al norte y sur del río las tierras regadas, respectivamente, por las acequias Alfatego-Dava y Churra-Turbedal, límites del área regada que durante el siglo XV se ampliarían mediante la desecación de terrenos pantanosos o almarjales, el alargamiento de acequias o la instalación de norias. Las tierras del regadío tradicional se cultivaban todo el año, mientras que se incorporaban al regadío o "huerta nueva" los almarjales situados a izquierda y derecha del río, desde la ciudad hasta la frontera con Orihuela, a través de un largo proceso de desecación. 
No obstante, después de enviadas las ordenanzas en 1495 se prosiguió desde el concejo la puesta a punto de esta reforma legislativa auspiciada por la monarquía. Se ha conservado un documento "suelto", catalogado dentro de un legajo municipal, que concreta y matiza algunas de las normas del regadío enviadas a los monarcas, aunque tampoco en este caso se precisa la fecha ${ }^{40}$, pero sirve para confirmar que el restablecimiento del orden en la huerta fue una compleja y laboriosa tarea de adaptación. Los acuerdos y enmiendas realizados fueron los siguientes:

- Rebaja de la multa por la entrada del ganado en la huerta: ganados cabañiles y cerriles de un real a medio, ganado menor $5 \mathrm{mrs}$./cabeza y puercos $10 \mathrm{mrs}$./ cabeza, así consta en el proyecto de ordenanzas que se envió a los monarcas en 1495, según se ha expuesto. Y se disminuía también la penalización de las bestias halladas en los cultivos (cereales, viñas, sotos o arboledas) por las que se pagarían en vez de $20 \mathrm{mrs}$./cabeza la mitad. Se aliviaban con ello los intereses de los ganaderos locales y mesteños. Sin embargo, respecto a lo regulado para el ganado que abastecía las carnicerías de la ciudad no se modificó nada, sino que se registrase el que había, y asimismo quedaban vigentes otras cláusulas que componían las leyes del regadío en 1495.

De todas formas, en octubre de 1496, el corregidor de Murcia Fernando de Barrientos ordenaba el cumplimiento de las ordenanzas redactadas por su antecesor Pedro Gómez de Setúba ${ }^{41}$ mientras los monarcas revisaran y aprobaran las enviadas en 1495. Así pues, la reforma legislativa quedaba en suspenso, aunque sí permanecían en vigor las antiguas

40 AMMU, Leg. 4276, $n^{\circ}$ 80, 1 f. Vid. A. Doc. $n^{\circ} 11$.

41 AMMU, Leg. 4281, nº 77, 2 ff. Vid. A. Doc. $\mathrm{n}^{\circ}$ 12: “...por quanto el rey e la reyna, nuestros sennores, por vna su carta firmada de sus nonbres, mandaron al liçençiado Pero Gomez de Setubar, corregidor que fue de la dicha çibdad, que de en çiertas personas del regimiento e çibdadanos de la dicha çibdad hiziese çiertas hordenanças para la guarda y buena guardaçion de la huerta de la dicha çibdad, y aquellas fechas las enbiasen a sus altezas para se confirmasen y aprouasen. Y entre tanto, el corregidor de la dicha çibdad proueyese y diese remate en la guarda de la huerta de la dicha çibdad, en tal manera que dos dannadores y malfechores fuesen castigados segund mas largamente por en la dicha carta de sus altezas (se) qontiene. Las quales dichas hordenanças fueron fechas y ordenadas por el dicho corregidor y regidores y çibdadanos de la dicha çibdad sobre mucho acuerdo y deliberaçion que para ello ouieron, y firmandose y aprouandose de las hordenanças antiguas açerca de lo susodicho antiguamente estauan fechas y aquellas fueron por la dicha çibdad aprouadas y enbiadas a sus alteças para que las confirmasen y aprouasen. Lo qual sus altezas no an podido ver ni hazer a cabsa de otros negoçios en que sus altezas y los sennores del su muy alto consejo estas ocupados de mayor ynportançia. Y en este tienpo, los grandes dannos y robos de la dicha huerta no an çesado ni çesan de cada dia, antes los clamores dellos an creçido y creçen a cabsa que en la dicha huerta no ay personas que tengan cargo ni cuydado de la guardar ni mirar por los dannos que en ellas se hazen y asy mismo porque las penas por donde hasta agora se a regido son tan baxas y çeuiles que por themor dellas los malos no dexan de robar y talar los panes $y$ esquilmos y frutas de la dicha huerta. Por ende, el dicho sennor corregidor, por virtud del poder a el dado por la dicha carta y prouision de sus altezas para proueher y dar remate en los dannos y talas de la dicha huerta, oydo el paresçer y platicas que sobreste caso muchas vezes con muchas personas a auido y an presentado lo que de todo ello es menester hazerse y proueherse para el remate dello dixo que mandaua y 
ordenanzas para ser aplicadas y poder remediar con ellas, en lo posible, la crisis del regadío, lo que no evitaba, al contrario, que se siguiesen reforzando las medidas o aplicando algunas novedosas y de urgencia. El regadío no podía quedar en un vacío legal. Y resulta muy interesante el documento inédito de 1496 que, según creemos, revela el eslabón perdido de las ordenanzas del regadío de 1495 y enlaza con el borrador de las de 1502 que aplicaban los "juramentados de la huerta" .

Esta nueva "institución" de juramentados, mencionada por primera vez en 1490 y que se superponía a la tradicional protección de los arrendadores y guardianes de la huerta, se registra posteriormente durante los años 1495-1496 y se explicita mucho más cuando, desde principios del siglo XVI, los murcianos fueron obligados por el concejo a organizarse en cuadrillas juramentadas de 40 hombres. A modo de policía rural, grupos de hombres de extracción popular vigilarían permanentemente la huerta para atajar un bandolerismo que se había acusado por la sequía de 1502. No parece haber duda, por el contenido del documento fechado en 1496, que se confirma el hallazgo de las ordenanzas "perdidas" de 1495 que se han comentado, y con ellas el eslabón que une el proceso de codificación del derecho de la huerta iniciado en 1479 y finalizado en 1503. En la segunda fase del mismo, correspondiente a las ordenanzas de 1495, los Reyes -o su Consejo Real- se demoraban en aprobarlas, aunque, según se ha indicado, no existía vacío legal alguno en el regadío al quedar vigentes las antiguas normativas, que sometían los asuntos de la huerta directamente a la autoridad del corregidor, lo que anulaba las atribuciones del concejo en dicha materia hasta la aprobación de las nuevas leyes. En julio de 1496, por unanimidad, se añadía a la ordenanza aprobada acerca del daño del ganado en el regadío que se pagase todo el perjuicio que ocasionase, lo que se ampliaba también dentro de las alquerías colindantes de la huerta, igualmente dependientes a la jurisdicción del corregidor: "el dicho sennor corregidor, por virtud del poder a el dado por la dicha carta y prouision de sus altezas para proueher y dar remate en los dannos y talas de la dicha huerta, oydo el paresçer y platicas que sobre este caso muchas vezes con muchas personas a auido y an presentado lo que de todo ello es menester hazerse y proueherse para el remate dello, dixo que mandaua y mando que las dichas hordenanças que asy fuesen fechas y ordenadas por el dicho corregidor y regidores y jurados y çibdadanos de la dicha çibdad, juntamentemente, sean guardadas y cunplidas y pregonadas..."43.

Los ejemplarizantes castigos corporales -100 azotes- a boyarizos, yeguarizos y pastores se sumaban a las multas establecidas. También se prohibía que estos hombres de

mando que las dichas hordenanças que asy fuesen fechas y ordenadas por el dicho corregidor y regidores y jurados y çibdadanos de la dicha çibdad, juntamentemente, sean guardadas y cunplidas y pregonadas". 42 AMMU, Leg. 4281, $\mathrm{n}^{\circ}$ 77, 2 ff. Vid. A. Doc. $\mathrm{n}^{\circ}$ 12: "Otrosy, porque la dicha huerta sea mas mirada y guardada que se nonbren y su merçed nonbrara çiertas personas que sean juramentados para que todas las calonias que vieren hazer las escriuan para que las penas en que cayeren, las quales hizieren sean exsecutadas conforme a las dichas hordenanças. Y destas todas penas lleue el arrendador de la dicha huerta la terçera parte, el tal juramentado la otra terçera parte y la otra terçera parte sea para el juez que lo exsecutare".

43 Ibidem. 
ganado llevaran armas (lanza, dardo, espada o ballesta) en la huerta, excepto cuchillo, "marracano" (¿cuchillo con mango pequeño?) o corvilla (guadaña o gancho).

En 1497, de nuevo, el concejo se proponía revisar las ordenanzas de la huerta para enmendar algunas en medio de un clima de aguda conflictividad social. Todavía en 1498, los regidores Manuel Arróniz y Pedro Riquelme, que en representación de la ciudad habían sido elegidos para asistir a las Cortes de Toledo de ese año, llevaban, en el memorial que presentarían a los monarcas, un total de 17 peticiones, de las cuales dos eran referentes al regadío murciano. En una se reivindicaba la aprobación de las ordenanzas de la guarda de la huerta commo sobre otras cosas tocantes a la buena gouernaçion desta çibdad... pues son tan justas y neçesarias para el bien y vtilidad desta çibdad; y en otra se solicitaba información acerca de la legalidad de la compra o aceptación de tierras que las instituciones religiosas venían efectuando en detrimento de la jurisdicción y fiscalidad del territorio integrado en el realengo murciano. Este hecho aumentaba la extensión del señorío eclesiástico de Alcantarilla y Alguazas (dos poblaciones y fértiles huertas del reino), ya de por sí extenso y feraz. Tras ello se presume la adquisición por parte de la Iglesia de tierras en la huerta concejil de Murcia, colindante con la eclesiástica de Alcantarilla, en detrimento de la extensión y jurisdicción de la primera. El objetivo de la petición en este asunto era que los monarcas prohibieran la compra o cesión de tierras en jurisdicción de realengo o, en cualquier caso, que no quedaran exentas de las contribuciones fiscales exigidas por el concejo ${ }^{44}$.

\subsection{La finalización del proceso codificador: la promulgación de las Ordenanzas de la Huerta en 1503}

La tercera fase del proceso de codificación de las leyes del regadío se fecha entre 1495 y 1502. En 1502, finalmente, se pudieron consensuar en un ambiente de dura oposición ${ }^{45}$ las ordenanzas que aprobaban poco después los Reyes el 6 de abril de 1503, aunque con alguna enmienda, en concreto la referida a la estancia de cualquier tipo de ganado en la huerta ${ }^{46}$. Los monarcas estaban bien informados del desorden social, económico e institucional que perduraba en el regadío, como exponían en el preámbulo de la carta, y confirmaban el 6 de abril de 1503 las ordenanzas de la huerta redactadas por el concejo de Murcia ${ }^{47}$, aunque enmendaba una referente a la entrada de ganado y animales en el regadío, como se ha mencionado. Las cuadrillas de 40 hombres juramentados,

\footnotetext{
${ }^{44}$ AMMU, Leg. 4281, $n^{\circ} 80$. Vid. A. Doc. $n^{\circ} 13$.

45 María Martínez, Unas ordenanzas inéditas..., pp. 27-29.

46 María Martínez, La cultura del agua ..., pp. 108-109: Se reforzaba la prohibición de la entrada y estancia del ganado en el regadío, a excepción de los de labranza. Se penalizaba la contravención, sin permiso concejil, con $30 \mathrm{mrs}$./cabeza y el doble si se hacía de noche, y la pérdida del ganado. Se especificaba también el reparto de las multas.

47 María Martínez, Unas ordenanzas inéditas..., pp. 64-65, nota 42. Antonio Gomariz, Documentos de los Reyes Católicos..., pp. 967-968. La ordenanza enmendada prohibía la entrada de cualquier ganado en la huerta sin licencia escrita del propietario de la tierra, bajo multa de $30 \mathrm{mrs}$. /cabeza o el doble si fuese de noche, además de pagar el perjuicio ocasionado.
} 
seleccionados por parroquias de la ciudad, fueron los encargados del cumplimiento de las "ordenanzas" de 1502, analizadas y editadas por Martínez ${ }^{48}$. Entre las competencias de esta policía rural se encontraba el registro de malhechores, delitos y multas y los daños ocasionados en el regadío. Ineficaz institución de base popular porque, pese a que informaban por escrito de las autorías y delitos, las penas no se ejecutaban por la ausencia del corregidor. No obstante, este fue sustituido por el pesquisidor, otro delegado regio, quien en 1502 y 1503 reconvenía a las justicias y oficiales de la huerta a que desempeñasen debidamente sus funciones y competencias ${ }^{49}$.

Las ordenanzas de 1502 se centraban en el gran problema del regadío: la estancia del ganado en los espacios de cultivo, por lo que elevaban las sanciones establecidas en las ordenanzas de 1495 a dos reales por cada par de animales encontrado en la huerta, además de la indemnización del daño en el plazo de 12 o 35 días, según se pagara en dinero o bienes raíces, respectivamente. Junto a las elevadas multas (1.000 mrs.) a los contraventores, se añadió el encarcelamiento de yeguarizos y boyarizos encargados del ganado. Y por otra parte, la preservación de los cultivos de la huerta (en concreto las viñas y los sotos) del paso de los animales por ellos se completaba con las nueve normas dispuestas. Ordenanzas de 1502, presumiblemente, que fueron enmendadas y sancionadas por los monarcas el 6 de abril de $1503^{50}$. En ellas, la monarquía ponía límites a la ganadería para proteger el regadío, o siquiera equilibrar las dos bases económicas más pujantes del reino con el fin de que la primera no fuese en detrimento de la segunda. La protección de la monarquía a la agricultura -y por ende a la base popular de la sociedad- limitaba los objetivos de los grandes ganaderos de la Mesta y de los locales, más interesados en la venta de la lana que en las rentas de la tierra, menos productivas que las obtenidas de los comerciantes que compraban la materia prima para abastecer la industria textil europea.

Como ha resumido Martínez: "la conflictividad resultante por el control de los pastos entre el ganado trashumante, el local y ambos con los propietarios del regadío creó una violencia generalizada socialmente que requirió la intervención del concejo y la protección de los intereses ganaderos y agrícolas mediantes normas jurídicas y ordenanzas" ${ }^{51}$.

La monarquía se enfrentaba a un conflicto de intereses sociales en el seno de la economía agropecuaria que trataron de impulsar. La documentación publicada, correspondiente a 1511-1516 (Juana I), muestra no solo el desequilibrio agricultura-ganadería sino la expansión acelerada de la segunda en claro perjuicio de la primera, o de la primacía de los intereses de los señores de ganado en perjuicio de pequeños o medianos agricultores, inmersos en un deterioro de su situación que les abocaba a la enfiteusis de las

48 María MARTínez, Unas ordenanzas inéditas...,pp. 83-95: Contienen 26 cláusulas para proteger los cultivos del exceso de proteccionismo ganadero, en la línea de las normativas analizadas pero con la aplicación de las ordenanzas por los "juramentados" de la huerta en un año crítico por la sequía.

49 María Martínez, Unas ordenanzas inéditas..., p. 44.

50 María Martínez, Unas ordenanzas inéditas..., pp. 48-49.

51 María Martínez, Unas ordenanzas inéditas..., p. 70, nota 71 y 77: Las actas capitulares del periodo (1495-1503) inciden en el problema ganadero sobre el regadío. 
tierras. La protección de los cultivos de regadío fue una constante difícil de solucionar que arrastraría la Edad Moderna. Por ejemplo, en 1512, se aprobaba y confirmaba la ordenanza que prohibía la entrada de ganados, bueyes y yeguas en "çierta parte de la dicha huerta que esta arbolada",52.

La ocupación de la huerta para estancia del ganado era perjudicial, y desde los inicios de la etapa castellana del reino, Alfonso X, había acotado una dehesa comunal para ello. Sin embargo, la realidad era que a lo largo de un proceso expansivo de la ganadería, imparable desde la segunda mitad del siglo XV, se habían privatizado "redondas" o sectores del regadío para pasto del ganado, con el perjuicio consiguiente para la agricultura. La venta de lana y seda a los mercaderes internacionales era más productiva y especulativa que los frutos de la tierra. Un problema que afectaba igualmente al regadío lorquino y de otras poblaciones murcianas ${ }^{53}$.

Algunos de los documentos editados correspondientes a la primera década del siglo XVI revelan problemas puntuales que eran denunciados por los afectados; así, en 1506 el jurado Francisco Tomás de Bobadilla manifestaba el agravio que recibía por el desorden existente en el reparto del agua de riego, y solicitaba que se distribuyese el "agua por yguales partes a los dichos herederos e que pudiese cada vno meter agua en su heredamiento pasandola por canal e por ençima del rio sin perjuyzio de nadie, porque diz el dicho Tomas de Vobadilla se le estorva mas el pasar de la dicha agua a su heredad que ha otros herederos... "54. En la misma fecha y también a instancias de la monarquía, el corregidor debía resolver judicialmente la denuncia presentada por Antón Abellán contra el regidor Pedro de Soto, referente al ganado cabruno que introducía en la huerta, "so color que los traen para la carniçeria de La Puebla", alquería-señorío de los Soto; además exponía el denunciante (denominado como "vno del pueblo") la connivencia entre los regidores y los alcaldes de la huerta, pues elegidos estos por el regimiento no ejecutaban las correspondientes multas en los regidores-propietarios de ganado que contravenían impunemente las ordenanzas establecidas al respecto por los Reyes Católicos ${ }^{55}$.

También los molinos hidráulicos, en continua expansión desde la segunda mitad del siglo XV, eran objeto de denuncia pues consumían el agua de riego, como exponía en 1507 el concejo murciano por el batán perteneciente al cabildo catedralicio que tomaba de la acequia de la Alquibla "mas agua de la que an de tomar e la mas del agua que

\footnotetext{
52 Antonio Gomariz Marín, Documentos de Juana I (1511-1516), XXIV, Real Academia Alfonso X el Sabio, Murcia, 2006, p. 311. El celo en defender el regadío de la intromisión del ganado suscitó denuncias, como la del oriolano mosén Gasco en 1512, a quien el concejo murciano le prohibió llevar su ganado a la propiedad que tenía en Beniel, dentro en los límites de la huerta de Murcia con Orihuela: Ibidem, p. 305. 53 Ibidem, pp. 311, 455 y 605: También la oligarquía lorquina ocupaba con sus ganados el espacio adehesado del regadío reservado al ganado de las carnicerías; en 1514 se denunciaba a la reina Juana este problema que encarecía, como consecuencia de este hecho, los precios de la carne.

54 Antonio Gomariz Marín, Documentos de Juana I (1505-1510), XXIII, Real Academia Alfonso X el Sabio, Murcia, 2006, p. 161.

55 Ibidem, pp. 162 y 167.
} 
toman diz que se vuelue al rio e se pierde... ",56. Por su parte, algunos de los regantes de la acequia de Zaraíche, en concreto los propietarios de tierra situadas desde el puente de "La Moleta" abajo, se quejaban de que los regantes-propietarios "de la Moleta de arriba" no les daban aguar para regar sus cultivos de cereal, e incluso "el agua que les sobra diz que maliciosamente la echan a perder antes que dargela" ${ }^{57}$. El consumo de agua para la energía molinar iba en perjuicio de la destinada para el riego de las tierras. La inversión en maquinaria hidráulica (molinos harineros y batanes) fue una nueva fuente de riqueza utilizada por los grandes propietarios de tierra y la oligarquía concejil, mucho más beneficiosa que las extraídas tradicionalmente de las rentas agrarias.

Agricultura intensiva trabajada por una mayoría social campesina degradada por el incremento de la gran propiedad y la expansión ganadera de los poderosos, pero también constante defensa de la huerta y desecación de almarjales para potenciar la producción de trigo. El decidido apoyo y la intervención de la monarquía de los Reyes Católicos en la política agraria e hidráulica de Murcia están bien documentados. En la Edad Moderna continuaría el proceso de panificación del regadío a costa de las tierras aluviales más bajas que estaban anegadas por el agua: un ejemplo, la reina Juana concedía en 1510 al regidor Pedro de Perea 2.000 tahúllas de tierra en el almarjal de Monteagudo "para sembrar pan" 58 .

\section{Recapitulación}

Desde el legado del regadío andalusí constituido en los siglos IX-X, la evolución histórica del regadío castellano durante la Baja Edad Media estuvo condicionada por el factor climático (aridez, escasas precipitaciones, evaporación, infiltración, etc.) sobre el que convergieron otros históricos (geopolíticos, socioeconómicos y culturales) que subrayan su carácter de subsistencia hasta bien entrado el siglo XV. Fueron muchas las transformaciones que se impusieron, pese a los preceptos alfonsíes para mantener las tradiciones islámicas. El cambio cultural imponía desde las bases heredadas una adaptación de las reglas del regadío a la nueva sociedad cristiana. Sobre el cúmulo de acuerdos compilados en la primera mitad del siglo XIV para regularlo, se irían estableciendo desde entonces modificaciones y matizaciones a los acuerdos, ordenamientos y ordenanzas. Serían las ordenanzas locales del trescientos las que grosso modo compilaban en parte la tradición andalusí y la adaptación del regadío a la mayoritaria sociedad cristiana que coexistía con una minoría rural mudéjar que había sido expropiada de sus tierras. Herencia y transformaciones posteriores materializadas en nuevos acuerdos, transformaciones y adiciones registrados en un códice del siglo XIV y en las sesiones concejiles que desde los años sesenta de esa centuria y la siguiente contienen las actas capitulares y otra documentación conservada en diversos legajos. Todo ello

\footnotetext{
Ibidem, p. 302.

Ibidem, p. 320.

8 Ibidem, p. 721.
} 
conforma las bases jurídico-administrativas del regadío medieval. Legislar el regadío fue necesario porque suponía el sostén económico de la sociedad murciana, tanto de la población capitalina como de la dispersa en las alquerías que formaban el poblamiento rural circundante.

La elaboración de las ordenanzas de la huerta recayó primero en el concejo de herederos o concejo rural que representaba a los propietarios del regadío, si bien sería absorbido progresivamente por el concejo urbano, cuya compilación de acuerdos y leyes realizaba a mediados del siglo XIV para tener información de los estatutos existentes e intervenir en los asuntos del regadío sometidos a su jurisdicción y competencia. La capacidad normativa de los propietarios regantes de los sectores de la huerta quedaba sujeta a la decisión del concejo. A partir de las ordenanzas del regadío existentes en 1479, los Reyes Católicos acometieron una reforma de la legislación, si bien hasta 1503 la monarquía de los Reyes Católicos no aprobaría definitivamente el derecho de la huerta con que se inauguraba la Edad Moderna. A lo largo del reinado de los Reyes Católicos, en tres secuencias temporales concretas $(1479,1495$ y 1503) que configuran el proceso de codificación del derecho huertano de finales del Medievo, se conseguiría la revisión, selección y consenso de las ordenanzas que aprobaron finalmente los monarcas para proteger el regadío. Un corpus de leyes renovado desde la tradición jurídica local (acuerdos y ordenanzas) que la monarquía promulgaba con carácter de vigencia y perdurabilidad para los nuevos tiempos modernos.

Dilatado proceso llevado a cabo durante 25 años que fue causa de conflictos sociales por las posiciones encontradas de divergentes intereses económicos (oligarquía, señores, grandes propietarios y ganaderos locales y mesteños frente a pequeños y medianos propietarios, agricultores enfitéuticos, jornaleros y braceros). La situación de la huerta, siempre acuciada por problemas seculares, se convirtió en crítica por la expansión ganadera local y mesteña que cruzaba la huerta para pastar durante el invierno en el vasto campo de Cartagena, más la impunidad y la dejación de las personas e instituciones encargadas de defenderla. Los Reyes Católicos no quisieron mantener en manos del concejo la solución de los problemas del regadío e impusieron su autoridad a través del corregimiento sobre la administración local. La monarquía fortalecida exigía diálogo social para elaborar una reglamentación más equilibrada y exigió la participación de los representantes de los dos grandes grupos sociales: baja nobleza local u oligarquía concejil por un lado y el común representado por los denominados ciudadanos. Y como moderador de ambos bloques para llegar al consenso de los estatutos del regadío se erigía el corregidor, forma de asegurar unas ordenanzas más justas que protegiesen los intereses agrícolas de la mayoría frente a la minoría de ganaderos de la que formaban parte algunos miembros de concejo, sus familiares y amigos. La soberanía regia se impuso y la reglamentación se consensuó para acabar con la desprotección del regadío, el desinterés de las justicias de la huerta, elegidas de entre la elite social, y la dejación y corruptelas de otros oficiales del común nombrados por el concejo para vigilarla. La reforma legislativa del regadío acometía problemas seculares acuciantes. 
La reforma se centraba en viejos problemas que acusaron las circunstancias históricas del periodo (guerras de Granada y guerras de Italia y efectos socioeconómicos de las mismas): mala distribución del agua y fraudes en el riego, robo de productos y materias, daños ocasionados por animales de labor, ganado ovino, porcino y caprino, deterioro de la red e infraestructura hidráulicas, delitos, infracciones e impunidad frente a la contravención de las ordenanzas, pues no se aplicaban ni ejecutaban por cohechos y "endogamia" entre autoridades e infractores, etc. El incumplimiento de las normas obligó a una sobrevigilancia en el regadío de base popular y a la decidida intervención de la monarquía a través del corregimiento, que debería imponer la justicia en la huerta al resultar esta ineficaz y corrupta en manos de las autoridades locales. Reforzar la seguridad del regadío fue una medida puntual a la que fueron obligados los murcianos desde los años noventa del siglo XV a través de unas cuadrillas juramentadas de base popular que se turnaban para vigilar la huerta y preservarla de malhechores, fraudes y componendas. Aunque "de facto" había muchas disposiciones reguladoras para el aprovechamiento del regadío y el corregidor asumía la máxima y directa competencia sobre los asuntos de la huerta, una rápida codificación y promulgación de las leyes del regadío murciano habría resultado eficaz con el fin de evitar las corruptelas, desacuerdos, desencuentros, oposiciones y un generalizado clima de malestar general a consecuencia del empobrecimiento del mundo rural: campesinos con pequeñas propiedades, trabajadores agrícolas de tierras gravadas con censos, abundante mano agraria de braceros y jornaleros formada por hombres, jóvenes, mujeres y servidumbre rural.

Ardua y conflictiva tarea ordenancista en pos del sostenimiento de la agricultura de riego, de un espacio que había sido enseñoreado y privatizado por la apropiación de las tierras comunales para dehesas, la presión de ganaderos y grandes propietarios, la degradación de las condiciones de vida de los huertanos, la dejación e impunidad derivadas de las corruptelas de quienes representaban a las instituciones administrativojudiciales y los divergentes intereses de ganaderos-grandes propietarios y pequeñosmedianos propietarios.

La demora en la elaboración de las leyes aumentó la confusión legislativa y el ambiente crispado de la población durante el dilatado proceso de constitución de unas nuevas ordenanzas de la huerta que entraban en los tiempos nuevos del absolutismo monárquico. Fueron finalmente unas normativas confirmadas por unos Reyes que habían dado sobradamente muestras de autoritarismo y se habían impuesto en el gobierno local a través de sus delegados con el fin de atemperar las divisiones sociales, controlar las funciones de los miembros del concejo y de las autoridades de la huerta y obligar al cumplimiento de una normativa que, revisada y consensuada con claras divisiones sociales y resistencias, fue finalmente enmendada, aprobada y promulgada por una monarquía fuerte y centralizada que se había superpuesto con este claro ejemplo legislativo al poder concejil y a los particularismos económicos. El corregidor fue para ello una figura clave.

No obstante, los resultados de la puesta en vigor del nuevo código de leyes huertanas no parece que de forma inmediata resultara eficaz, como tampoco la política agraria 
e hidráulica establecida por los monarcas, pues el adehesamiento y privatización del regadío con el establecimiento de "redondas" en el mismo por parte de la oligarquía concejil (dueña de tierras y ganado) y las inundaciones de la huerta por las crecidas del río Segura (y la destrucción de la red hidráulica ${ }^{59}$ ) siguieron siendo los dos grandes problemas de la huerta de Murcia al comenzar la Edad Moderna ${ }^{60}$. Pero también con leyes renovadas comenzaba la lenta ruptura con el regadío clásico medieval y la configuración de una "nueva huerta" que se mantendría hasta la primera mitad del siglo XX.

\section{APÉNDICE DOCUMENTAL}

\section{1}

\section{(Década de los setenta ${ }^{61}$ ): Ordenanzas acerca de las penas impuestas por el concejo de Murcia a quienes causaran daños en el regadío (AMMU, Leg. 4276, $\mathbf{n}^{\mathbf{0}}$ 63, 2 ff. ).}

(f. 1 r.) Miercoles XXV de março; testigos, Rodrigo Vazquez, merino, e Alonso Mercader e Ferran Royz Delgadillo e Martin Diaz de Albarraz e Juan Alonso de Magaz e Alonso Rodriguez, veçinos de Murçia.

Sepan todos que por quanto el conçejo, regidores, caualleros, escuderos, ofiçiales e ommes buenos de la muy noble çibdad de Murçia han seydo enformados e les han seydo dados muchas quexas de muchas talas e males e dannos que se han fecho e fazen de cada dia en los panes e vinnas e alcaçeres e yeruas e en otros esquilmos de la huerta desta çibdad, asy por ommes commo por bueyes e vacas e ganados e otros bestiares, auiendo poco temor de la justiçia e de las penas acerca dello puestas e ordenadas, que han encomendado e encargado la sobreguarda de la dicha huerta fasta ser conplido el arrendamiento de los guardianes deste presente anno, porque se pongan en ello algund castigo e escarmiento e se escriuieren los dichos dannos, a Sancho de Daualos, vno de los regidores de la dicha çibdad, al qual dieron poder para ello e para poner las guardas que cunplieren acerca dello con estas condiçiones e penas yuso escriptas, para que las exsecute en aquellas personas que los tales males e dannos fizieren, asi por sy mesmos commo por sus bueyes e vacas e ganados e bestiares, las quales son las siguientes:

(f. 1 v.) Primeramente, que los bueyes e yeguas e asemilas e roçines que fueren fallados por las dichas sobreguardas faziendo danno en la dicha huerta, que paguen de pena por cada par sy fueren fallados de dia medio florin e de noche vn florin.

59 AMMU, Leg. $4276, n^{\circ} 86$. A. Doc. $n^{\circ} 14$ : se transcribe la minuta del concejo destinada a recabar ayuda de la monarquía para paliar las inundaciones. Sobre este histórico problema MARTínEz, La cultura del agua ..., pp. 85-87.

60 Guy Lemeunier, "L'irrigation à Murcie au debut de 1'epoque moderne", Castrum, 5 (1999), pp. 91-100.

${ }_{61}^{61}$ En 1472 y 1478 el 25 de marzo era miércoles, pero puesto que en 1479 existe un índice que registra la existencia de "ciertas ordenanças para la guarda de la huerta" (Vid. A. Doc. $\mathrm{n}^{\circ}$ 2), se considera como fecha más probable la de 1478. 
E por cada cabeça de vacas que fuere fallada, de dia vn florin e de noche dos florines, e por cada asno que fuere fallado, de dia çinco maravedis e de noche diez maravedis. E por cada cabeça de ganado lanar e cabrio e puercos que fuere fallado, de dia çinco maravedis e de noche diez maravedis.

E qualquier omme que fuere fallado segando en pan alguno o legumbres o yerua alguna, alcaçeres o alfafas o alcadias o otras yeruas que pague de pena, de dia, çinquenta meravedis, de noche çient maravedis.

E que ninguno non sea osado de segar yerua en marjen ajeno nin amarjene las bestias alinde de pan nin de otro esquilmo, en pena de seys maravedis de dia e doze maravedis de noche.

E qualesquier personas que fueren fallados en reales çerrados, que paguen de pena, $(f$. $2 r$.) de dia dozientos marauedis e de noche quatroçientos maranedis sy fuere vezino de la dicha çibdad, e sy non fuere vezino de la çibdad que lo pongan en la carçel e este alli treinta dias e que pague las dichas penas.

En todo lo al que non alcança estas ordenanças que se recurran a la ordenanças de la huerta.

E que las dichas penas de suso declaradas sean para el dicho Sancho de Daualos commo exsecutor dellas e para las guardas que el por sy pusiere en la dicha huerta.

E mandaron lo asi pregonar publicamente por esta çibdad, porque todos lo sepan e venga a sus noticias e non puedan allegar ynorançia diçiendo que lo non supieron.

\section{2}

\section{9- VII-18: Índice de ordenanzas diversas aprobadas por el concejo de Murcia en 1479 (AMMU, Leg. 4291, $\mathrm{n}^{0} 18,13 \mathrm{ff}^{62}$ ).}

Ordenanças huerta. Sabado XVIII de julio estan çiertas ordenanças para la guarda de la huerta.

Tabla. Este dia, el arrendamiento e remate de la tabla de las açequias.

Aguera. Sabado XXIIII dias de julio esta el asyento que el consejo fizo con Juan de Aguera sobre çiertos arboles parras que ha de mudar en su heredad.

Agua Librilla. Este dia (sabado XXI de julio) esta vn acto sobre el agua que los de Librilla tienen ocupada del rio de Sangonera.

Boqueras açequias. Este dia, esta la ordenança de los que desbaratan boqueras de açequias.

62 Se transcriben solamente las relacionadas con la huerta. 
Villora ganados. Martes XIIII de setienbre, ay ordenanças que ningunos ganados no entren en Villora.

Que no riegen con rafa, En este dia esta que ninguno sea osado de regar con rafa syno aquellas personas que mostraren que lo han acostunbrado de regar de çinquenta annos a esta parte e han pagado las tajas del açud de las que riegan.

Que non fagan rafa syn liçençia del conçejo. En este dia, esta de como reuocaron el poder que dieron a Alonso Garçia para dar liçençia para fazer rafa. E mandaron que ninguno no la faga syn liçençia del consejo.

Guardas. Jueves, XXVII de enero, esta que non sean guardas saluo los nonbrados en conçejo.

Hermandad. En este dia mandaron que se arrienden las penas de la huerta de la Hermandad.

Penas de la huerta pertenecientes a la Hermandad. Sabado XXVI de febrero, en este dia esta que se arrienden las penas de la huerta perteneçientes a la Hermandad.

Ganados huerta. Sabado XI de março, esta que el ganado que non es de la huerta non ande por la huerta, so pena de diez mil marauedis.

Ryo. En este dia de commo dieron a çiertos regidores e jurados para entender sobre los desprendimientos del rio.

Despendimientos rio. En este dia esta el poder que dieron a çiertos regidores e jurados e çibdadanos para los despidemientos del ryo.

Ordenanças Sangonera. E que esta vnas ordenanças de Sangonera.

(Hacia finales de los ochenta del siglo XV): Petición de cuatro propietarios de Monteagudo y Casillas reclamando el derecho que tenían para llevar sus ganados a pastar en la huerta sin dañar los cultivos (AMMU, Leg. 4287, $\mathbf{n}^{\circ}$ 83, s.f., 1 f.).

Muy magnificos e virtuosos sennores

Alonso de Manresa e Gonçalo de Jumilla e Gines de Manresa e Françisco Jaymez, veçinos desta muy noble e leal çibdad de Murçia, por nosotros mismos y en nonbre de los otros herederos de los heredamientos de Casyllas e el Rincon de Montagudo, besamos las manos de vuestra merçed. A la qual fazemos saber que por virtud de vna hordenança antigua que los herederos de los dichos heredamientos tienen, los dichos herederos dormian e han acostunbrado dormir con sus bestiares fuera del corral en aquellos lugares e prados mas desenbargados guardando de no hazer danno ninguno en los panes nin otros esquilmos, por virtud de la qual dicha hordenança avemos estado 
en esta costumbre e avemos dormido con los dichos nuestros bestiares, segund dicho es. E agora, a nuestra notiçia es venido que vuestra merçed, este otro dia pasado, mando pregonar vna hordenança en que se contiene que ningund bestiar de los heredamientos e alquerias debaxo non duerma fuera del corral sino que vengan a dormir a los corrales e lugares acostunbrados, so çierta pena en la dicha hordenança contenida. El qual pregon por nosotros nunca fue sabido nin ha venido a nuestra notiçia fasta agora que por virtud del dicho pregon e hordenanças los alcaldes de la huerta desta dicha çibdad nos han mandado prendar e prendaron dizyendo aver incurrido en la pena en la dicha hordenança contenida.

Suplicamos a vuestra merçed, pues por virtud de la dicha nuestra hordenança nuestros bestiares dormian en la dicha huerta y el pregon e hordenança que vuestra merçed mando fazer fasta agora no es venido nin vino a nuestra notiçia, que sy nosotros lo supieramos luego obedeçeriamos e cunpliriamos el mandamiento de vuestra merçed. Nos manden tornar nuestras prendas que nos tienen por razon de lo susodicho e de aqui adelante nosotros queremos guardar e conplir el mandamiento de la vuestra merçed e no eçeder en ninguna cosa del, segund que por vuestra merçed es mandado. En lo qual vuestra merçed, si lo asy mandar fazer, nos haria bien e e merçed. Cuyas vidas e salud nuestro Sennor propere e guarde commo por vuestra merçed es deseado.

\section{(Hacia finales de los ochenta del siglo XV): Solicitud de Diego Riquelme al concejo para que revocase la ordenanza que obliga a poner boqueras en la acequia del Turbedal (AMMU, Leg. 4287, $\mathrm{n}^{0}$ 103, 1 f.).}

Diego Riquelme, commo procurador y en nonbre de todos los herederos de la açequia de Turbedal, beso las manos de vuestras merçedes y digo que a notiçia mia es venido que vuestras merçedes mandan poner acoda en las boqueras de todas las açequias, haziendo en la boquera una manera de ventana para que no pueda tomar mas agua de aquella que le pertenesçe. Y sennores, la dicha açequia de Turbedal no es de la condiçion de las otras porque hordenariamente los mas de los annos uienen aguaduchos de Sangonera y envisten la dicha açequia de Turbedal fasta ensima de los quixeros; $y$ sy la tal boquera hallase tan estrechamente puesta no seria mucho que cada vn anno la dicha açequia la ouiesemos de hazer de nueno. Porque suplico a vuestras merçedes la dicha boquera la manden ver y asy vista hagan aquello que fuese justiçia, dandonos el agua que nos pertenesçe y dexandonos nuestra boquera desenbargada para que los aguaduchos puedan entrar y salir desenbargadamente. 
(Hacia finales de los ochenta del siglo XV): Solicitud de Pedro Avilés al concejo para tener 200 cerdos dentro del regadío por ser el abastecedor de las carnicerías (AMMU, Leg. 4287, $n^{\circ}$ 42, 1 f.).

Muy magnificos y virtuosos sennores

Pedro de Aviles, carniçero, vuestro vezino, con umille reuerençia que deuo, beso vuestras manos e me encomiendo en vuestra merçed. A la qual fago saber que yo tengo para la prouisyon desta çibdad dozientas cabeças de puercos, los quales continuamente tengo de matar e porque me seria grand trabajo sy los oviese de tener fuera de la huerta e porque los annos pasados se a fecho, suplico a vuestra merçed me de liçençia para que los pueda tener por la huerta con las condiçiones del ganado de las carneçerias. En lo qual, sennores, allende de fazer lo que soys obligados por ser para la prouisyon de la çibdad, yo, sennores, resçebire mereçed, ofresçiendome que acabadas, sy merçed vuestra fuese, contento yo trahere mas.

Nuestro Sennor vuestras virtuosas personas prospere con mayor estado a su seruiçio.

1484-VII-13: Denuncia y reclamación de Bartolomé Vidal al concejo por la expropiación impagada de una tierra y otros daños ocasionados por la construcción de un canal en la Puerta de las Menoretas (AMMU, Leg. 4280, ${ }^{0}$ 65, 1 f.).

Bartolome Vidal, vezino desta noble çibdad de Murçia, paresco ante la merçed vuestra, en la qual notifico e hago saber que muchos dias ha que vos, sennores, trayendo sana el agua que se recoje en el Bovar de la Puerta de Las Menoretas, mandastes hazer vn escorridor, el qual tomo de vna heredad que en la dicha Puerta de las Menoretas yo tengo, segund que es cierto vna tafulla poco menos, la qual tafulla, nunca por la merçed vuestra me fue pagada ni mandada pagar. E allende del danno que en esto resçebi por la dicha tafulla que asy tengo perdida pago de çienso en cada vn anno al hospital de san Julian ochenta marauedis. E agora, allende del agrauio que resçibo en lo susodicho tengo, faziendome mayor agrauio e syn razon al edefiçio de riego que tengo para regar la dicha heredad e tafullas, Juan Perez de Valladolid, jurado, no se por que ni por cuyo mandado ha abierto el dicho escorredor e destruydo e del todo desfecho el lugar por donde regaua, e asy la dicha mi heredad queda de regadio que hera de secano e de prouechosa esterill que por falta del riego he perdido e pierdo muchos esquilmos que pudiera fazer en la dicha mi heredad. Es notorio a todos los 
vecinos que alli tienen heredades que valient en este anno dos mil marauedis e mas e a cabsa de me aver desfazer el dicho Valladolid el lugar por donde riegan los pierdo $o$ dexo de fazer el dicho esquilmo.

Por ende, a la merçed vuestra suplico que me provea e remedie con justicia e me mande pagar la tierra que pierdo e se me toma de mi heredad que estaua en tres mil marauedis e me mande rehacer el lugar para donde riegue la heredad que me queda. Lo qual la merçed vuestra deue mandar fazer, pues que soys puestos ara desfazer los agrauios que en la çibdad se hacen e no se aya de dezir que quien me ha de hazer e cumplir de justicia me haze el agrauio o la ynjustiçia. E si la merçed vuestra asi lo fiziere fara bien e yo lo resçebire en merçed. En otra manera protesto de me querellar al rey e reyna, nuestros sennores, e de cobrar las costas e dannos de quien de derecho deua. E por como lo digo pido al notario presente testimonio. E pido la merçed vuestra que me haga conplimiento de justicia.

\section{5-III-16: Queja de Antón Sánchez porque Juan Hidalgo pretende quitarle ocho tahúllas de tierra de riego (Leg. $4281, n^{\circ} 6,1$ f.).}

Muy virtuosos sennores

Anton Sanchez, vezino desta muy noble çibdad de Murçia, me encomiendo en vuestra merçed. A la qual plega saber commo yo tengo a mediado fasta ocho tahullas dadas en censo de Juan Hidalgo por çiertos annos; e agora que las tengo bien procurades por me las quitar y lleuar mi trabajo e an de me leuantado rebcado e enplazome para ante el sennor alcalde del noble sennor corregidor. E pidiome dos mill marauedis, y commo yo sea onbre de mi lauor de poco saber en pleitos nin en otras cosas por non responder quede confuso y el sennor alcalde me condeno. Suplico a vuestra merçed commo juezes de apelaçion superiores me manden remediar de justiçia, por manera que por achares no me quiera lleuar lo que non tengo, mandando vereis la demanda que me puso e sin me oyr a mi a cosa que contra ella querra dezir, saluo tan solamente saber vuestra merçed la verdad si lo que me pide es justo y le soy embargo dello me lo mande pagar, e la otra manera non reçiba tan gran agrauio e perjuicio, que sy non le soy embargo por achares de non saber responder en gran cargo de su conçiençia me aya de lleuar lo que non tengo para lo pagar, mirando mi miseria y pobreza.

En lo qual vuestra merçed fara seruiçio a Dios y a mi gran merçed. Y las muy virtuosas personas de vuestra merçed guarde de nuestro sennor commo por vuestra merçed es deseado. 


\section{8}

\section{3-III-4, Loja. Carta del concejo de Loja al de Murcia, solicitando traslado de las ordenanzas murcianas sobre riego (AMMU, Leg. 4281, $n^{0} 57 ., 1$ f.).}

Muy virtuosos sennores, conçejo, justiçia, regidores, caualleros, ofiçiales, ommes buenos de la muy noble çibdad de Murçia. Nos, el justiçia, regidores, caualleros, oficiales, ommes buenos de la noble íbad de Loxa, nos encomendamos en la merçed vuestra e vos fazemos, sennores, saber commo por ser esta çibdad nuevamente poblada esta en necesidad de hordenanças buenas de las aguas e riego de las heredades; e porque avemos sabido que las hordenanças desa çibdad cerca desto son las mejores destos reynos, acordamos de escreuir carta. El sennor Diego Fajardo, que se acaesçio y ralla pidiendos, sennores, por merçed nod querays mandar vn trelado dellas para que por las conformes a la dispusiçion desta tierra nos rijamos. En lo qual, sennores, reçebyremos especial merçed e asy haremos aca en lo que posible fuere lo que, sennores, mandaredes. E nuestro Sennor vuerstras virtuosas personas e estado desa muy noble çibdad aprueue.

De la çibdad de Loxa, a quatro de março de IMCCCCXCIII annos.

Diego Fajardo, Hernando de Herrera, Alonso de Peralta, Yñigo de Arroyo, Rodrigo Rodriguez.

Yo, Alonso Gonçalez de Valençia, escriuano del rey nuestro sennor e su notario publico e escriuano del cabildo de la çibdad de Loxa, en lugar de Gonçalo Garçia de Toledo, la escriui por mandado de los sennores del ayuntamiento.

1494-VIII-20: Solicitud de Isabel de Valenzuela para que no le embargara el concejo cinco tahúllas de tierra sitas en la Puerta de Las Menoretas (AMMU, Leg. $4287, n^{0} 11,1$ f.).

\section{Nobles sennores}

Ysabel de Valençuela, mujer de Juan de Balibrera, defunto, besa las manos de vuestras merçedes, y les haze saber commo a su pedimiento y por su mandado me an querido prendar Pero Lopez diziendo que cinco tahullas que yo tengo e poseo en las Menoretas, que afrentan con el Bovar, son pecheras al Bovar, y en virtud las dichas tahullas non son pecheras al Bovar, en tal pecho nin tributo se an pagado y no se prueua ser çinco tahullas, saluo vna y tres quartas, porque las otras son de los herederos de Martin Lopez e de Jayme del Castillo, la qual tahulla e tres quartas no escurre en el Bovar por estar commo esta el adarbe viejo delante las dichas tahulla e tres quartas. E sy por 
ventura saltare algund agua por ençima mandeme prendar, pero pues no escurren la dicha tahulla e tres quartas en el dicho Bovar ayan por bien de no las hazer pecheras, pues pido a vuestras merçedes non lo manden prendar pues que no deven ser alguna y para mi justificaçion de lo susodicho vuestras merçedes lo manden ver en lo qual vuestras merçedes administraran justiçia y a mi me haran bien e merçed.

1495 (fecha probable): Ordenanzas de la huerta de Murcia (AMMU, Leg. 4287, $n^{0} 67$ bis, 3 ff).

(f. 1 r.) Otrosy, por quanto algunas personas con demasiada codiçia y (roto) de la justiçia mudan las hitas de entre vnos heredamientos, de lo qual subçeden muchos pleitos e quistiones e (contrastos?). Por ende, mandaron que personas algunas no sean osados de mudar las dichas hitas nin quitallas, asi las que estan puestas en los heredamientos del regadio commo en los secanos, e se pusieren por cada vez de pena de seysçientos maranedis, el terçio para la çibdad y el terçio para el acusador y el terçio para el juez que lo executare.

Otrosy, qualquier persona que se entrare en marjen ajeno que incurra en çiento e çinquenta marauedis de pena, partidos como dicho es, e a su costa se torne el marjen a debido estado.

Otrosy, por quanto a cabsa que muchos veçinos desta çibdad no saben nin oyen el pregon que los dezmeros de las moreras hazen para yr a dezmar la hoja dellas, non van los duennos dellas a estar presentes e los dichos dezmeros diezman commo quyeren a su provecho, de que algunos veçinos resçiben danno e perjuyzio. Por ende, mandaron que los dichos dezmeros non hagan hazer los dichos pregones por vna abtoridad sola sino que quando quisieren dezmar algund quarto o parte de la guerta lo digan al escriuano del ayuntamiento y el lo haga pregonar por todos los lugares acostunbrados al pregonero de la çíbdad, porque algunos duennos de los dichos morerales non podian yr por enfermedad o por absençia o por sus mujeres viudas. Que la çibdad de cada vn anno, al tienpo del dicho dezmar, nonbre vna persona buena que tenga sabiduria en el dicho dezmar e baya con los dichos dezmeros en lugar de las personas que no pudieren yr, e que la çibdad le de de sus propios su salario justo; e si no lo hizieren, todo lo que dezmaren sean en si ninguno e se torne a hazer en la manera susodicha.

Otrosy, porque algunas personas que son prendadas por algunos dannos o penas non quieren paresçer ante los juezes a alegar su defensa pensando que sin oyllos no los pueden condenar. Por ende, mandaron que despues de diez dias que le prendan (e) le fuere sacado de su casa, sea obligado de venir a responder; e si no vinieren que los juezes, pasados los diez dias, le manden çertificar e notifiquen de remate 
personalmente en su casa no pudiendo ser avido; e si paresçiere, sea oydo y si no le puedan rematar e tener la prenda como si fuese oydo.

(f. 1v.) Otrosy, porque en la huerta desta çibdad ay muchas açequias e braçales que traviesan los caminos publicos e los procuradores e herederos de las dichas açequias e braçales son obligados de hazer sus puentes de cal e adrillo, e a cabsa de no hazerse se sonriegan los caminos e resçiben mucho danno los caminantes. Por ende, hordenaron que los sobreaçequieros de la dicha çibdad o qualquier dellos requieran los dichos caminos e manden por ante escriuano a los dichos (procuradores) e do no ovieren procurador a quatro herederos de las dichas açequias o braçales, que dentro de treinta dias hagan los dichos puentes o adoben los que no estan bien hechos de la manera que el camino lo requiere; e si el dicho procurador o herederos no lo hizieren asy dentro del dicho termino que los dichos sobreaçequieros o qualquier dellos lo hagan hazer a costa de los dichos procuradores o herederos; e demas de lo que el dicho sobreaçequiero gastare en el hazer o reparar dellos haziendolo a estajo o por jornales lleve por su trabajo el quarto de lo que la dicha costa montare del dicho procurador o herederos demas de lo prençipal. Lo qual todo puedan luego exsecutar y entregarse dello de los bienes de los dichos procurador o herederos sin los oyr ni çitar, sino solamente haziendo juramento ante el escriuano del ayuntamiento que gasto en el dicho puente los dichos marauedis e lo firme de su nombre.

Otrosy, porque algunos esclavos negros o blancos hurtan leña e fruta e yerva de la hazienda de sus amos e de otros y la venden a los carreteros y otras personas; por ende, mandaron que persona alguna conpre lenna de la huerta ni fruta ni yerva, so pena de çien marauedis, partidos commo dicho es, e de perder el preçio que diere por ello. Otrosy que persona alguna no pida ni lleve mas de vn real por cada yegua por trillar vn dia ni por otras bestias algunas, so pena de vn real por cada vez, partido commo dicho es. Otrosy, porque muchas personas de noche hazen muchos daños en la huerta a sabiendas con sus personas e ganados e bestiares e avnque despues se sabe se quieren escriuir de la pena diziendo que pues no fueron tomadas ni escriptas que non den (roto).

(f. 2 r.) Que digan de donde traen la fruta y otras cosas ${ }^{63}$ :

Otrosy, hordenaron e mandaron que los guardianes de la huerta e otras qualesquier guardas e juramentados que por çibdad toviere puestos e nonbrados para guardar la dicha huerta si fallaren alguna o algunas personas que truxeren de la dicha huerta qualesquier frutas o lenna o yervas o otras qualesquier cosas e sospechese que aquellos lo traen de lo ageno puedan les parar y saber de que lo traen (e) de donde lo traen. Y los tales sean obligados de dezir y mostrar al guardian o juramentado donde lo traen; e si fallaren que de lo ageno lo traen lo pueda escrivir e pague el tal la pena ordenada por el danno a su señor con el doblo, segund dicho es, asi como si fuere tomado haziendolo. Prenden a los dannadores ${ }^{64}$.

63 Escrito en el margen izquierdo.

64 Escrito en el margen izquierdo. 
Otrosy, hordenaron e mandaron que todos los vezinos de la dich a çibdad e sus labradores o mozos que hallaren en lo suyo algunas personas, hombres commo mujeres o ganados o bestiares haziendo danno puedanlas prendar e traer las prendas ante el dicho sennor e alcaldes e escrevir e demandar esecuçion de la pena y el danno contenido en estas hordenanzas. E si el tal dannador resistiere las tales prendas al tal sennor de la dicha heredad o labrado o tierra caya e incurra en pena por cada vez que la tal resistençia ha de çiento e çinquenta marauedis, partidos segund e commo dicho es.

Otrosy, hordenaron e mandaron que los guardianes que arrendaren las penas de la dicha huerta y los sennores de las heredades y sus onbres o moços o labradores y todo otro honbre bueno, vezino o herederos en la dicha huerta que vieren o hallaren haziendo algund danno, asy por personas commo por bestias o ganados avnque sea en lo ageno puedalo escrevir e el llevar su parte y sea creydo por su juramento y los dichos juezes lo juzguen y executen las tales penas conforme a estas hordenanças.

Otrosy, hordenaron e mandaron que sy alguna o algunas personas cayesen o incurriesen en algunas penas e calonias por algunos dannos que fizieren e porque fueren contra estas hordenanzas e non tovieren bienes de que pagar las tales penas, que esten diez dias en la carçel dexando su derecho a (salvo) para que si algund danno oviere fecho (2 v.) que su duenno ge lo pueda pedir segund derecho o soltarselo si quysiere.

Los guardianes hagan saber los dannos ${ }^{65}$ :

Otrosy, hordenaron e mandaron que los alcaldes de la guerta e guardianes e arrendadores de las penas e calonias de la dicha huerta quando hallaren algunas personas o bestiares haziendo dannos algunos contra lo en estas hordenanças contenidas, luego, aquel dia o otro signado, haganlo saber a los sennores cuyas fueren las heredades donde fueren fallados los tales dannos o en sus casas para que aquellos pidan su danno sy quisieren y escrivan las tales penas e calonias ante el escriuano de la dicha huerta dentro del terçero dia, so pena que si ansi non lo hiziere que el tal guardian pague la dicha pena y el danno que el tal dannador avia de pagar; e demas si se hallare que el tal guardian se aviniere o ygualare con el tal dannador por la dicha pena e no la escriviere en el dicho termino por se aver igualado con el, que le sean dados çien açotes publicamente.

Que el guardian non traya fruta ${ }^{66}$.

Otrosy, hordenaron e mandaron que los dichos guardianes no sean osados de coger ni tomar ninguna fruta ni otras cosas ningunas de lo ageno ni de lo traer de lo suyo, so pena de çien marauedis al tal guardian, partidos commo dicho es, eçebto sy ante testigos no lo cogexe o traxere de lo suyo.

Frutas $^{67}$ :

65 Escrito en el margen izquierdo.

66 Escrito en el margen izquierdo.

67 Escrito en el margen izquierdo. 
Otrosy, hordenaron e mandaron que ningunas personas no sean osados de entrar con fruta en la çíbdad avnque sea de lo suyo, en verano despues de las diez y en ynbierno despues de las nueve ni antes de el sol salido, so pena de çien marauedis, partidos commo dicho es.

Alquerias $^{68}$ :

Otrosy, hordenaron e mandaron que todos los herederos de las alquerias que son fuera de las açequias de la huerta de la dicha çibdad pue-

(f. 3 r.) Guardianes ${ }^{69}$ :

dan poner e pongan sus guardianes cada vno en la guerta, con tanto que el juzgar y executar venga y (roto) ante el señor corregidor y executores desta dicha çibdad e por las dichas hordenanças.

Otrosy, hordenaron e mandaron que ningunos ganados, puercos, cabras ni ovejas ni otros ganados cabañiles ni çerriles ny de lavor no sean osados de hazer danno en los açarbes de la huerta ni en las açequias della ni travesar por ella por escusar los dannos que en las dichas açequias y açarbes fazen, so pena a qualquier bestiar çerril o de lavor o ganado cabañil mayor de vn real por cada cabeça e a los (puercos) de medio real por cabeça y al ganado menudo diez marauedis por (cabeça), todo partido commo dicho es; e demas que enmienden el danno e den con el doblo a la dicha açequia o açarbe y esto sea (para) los ganados cabañiles o çerriles, tienen por la (entrada de) la guerta en la hordenança ante desta.

Entregador ${ }^{70}$ :

Otrosy, hordenaron e mandaron que el dicho señor corregidor e alcaldes de la dicha guerta ayan e tengan entregador a contentamiento de la çibdad y presentado en el ayuntamiento, el qual prende y lleve a exsecuçion todas las penas e calonias e dannos de la dicha huerta que por el dicho señor corregidor e alcaldes de la huerta fueren mandadas exsecutar y entregar y pagar (e que) lo que ovieren de aver, asi de las partes de la pena commo de (mancha), dentro de diez dias que le fueren mandadas executar e den por razon de su trabajo e salario de la dicha exsecuçion el diezmo de lo que montaren toda la dicha pena, asi de la de los dichos juezes commo del acusador y açequias. Lo qual se obligue de lo exsecutar y cobrar e pagar a las partes dentro en el dicho (termino) e sino que la pagaran e paguen de sus bienes. E avnque las partes puedan cobrar sus partes despues de exsecutada la pena, (que) el dicho entregador non prenda su diezmo, mas que lo cobre de los acusadores, (si) seyendo su voluntad non la quisieren soltar.

(f. 3 v.) Otrosy, hordenaron e mandaron que ninguna ni algunas personas no sean osados de tajar con texa ni hierro ni quebrar con cuchillo ni con destral ni con açada ni con otra cosa que pueda hazer daño en la puente mayor del conçejo ni en ningunas

68 Escrito en el margen izquierdo.

69 Escrito en el margen izquierdo.

70 Escrito en el margen izquierdo. 
otras puentes de las huertas de las açequias ni açarbes, so pena a qualquier que lo susodicho hiziere, seyendo el danno notorio en la puente mayor, que caya e incurra en pena de çien marauedis y en las otras puentes menores çinquenta marauedis, todo partido commo dicho es, e de hemendar el danno que en las dichas puentes hizieren con el doblo.

Otrosy, hordenaron e mandaron que ninguna nin algunas personas no sean osados de llevar ni hurtar piedras de las balsas e de lugares agenos sin voluntad de su sennor, so pena de çien marauedis a cada vno que lo contrario hiziere, partidos commo dicho es, e que enmienden las piedras que ansy tomaren o hurtaren con el doblo.

Otrosy, hordenaron e mandaron que todas e qualesquier personas quien fueren fechos dannos o talas en las dichas huertas, asy por personas commo por ganados o bestias mayores o menores, si lo quisieren demandar que lo demanden e aya demandado dentro de veynte dias que ellos vieren o supieren que el tal danno les fue fecho, no lo puedan demandar ni pedir que y sean creydos por su juramento, ellos e sus hijos o criados o labradores, y se entienda asy en el secano como en el regadio.

Otrosy, hordenaron e mandaron que en todos los heredamientos de la huerta de todas e qualesquier personas, asy caballeros commo otros (de) qualesquier estado o condiçion preminençia o dinidad que sean que esten dentro de las açequias se guarden estas hordenanças y se esxecuten e lleven las penas e calonias en ellas contenidas; $e$ que ninguno pueda dello ser exçebtado.

(1495-1496, aproximadamente): Revisión de las ordenanzas que prohibían la entrada del ganado en el regadío (AMMU, Leg. 4276, $\mathrm{n}^{\circ}$ 80, 1 f.).

(f. 1 r.) En la hordenança que habla que non entren los ganados cabañiles ni çerriles en la huerta e regadio desta çibdad enmendan la dicha ordenança de la pena en que dize que incurran en pena los ganados mayores cabañiles y çerriles, por cada vez, cada cabeça, vn real. Mandaron que no sea mas de medio real por cabeça y a los otros ganados menores çinco maravedis por cabeça y a los puercos diez maravedis por cabeça, repartidos como la hordenança lo manda. Y que las dichas escripturas no las puedan hazer synon los arrendadores de la huerta que esten obligados con los dannadores o los guardianes puestos, por ellos o las otras personas puestos por la çibdad. Y que lo demas dexaron la dicha hordenanza en su fuerça y vigor.

A la quarta hordenança que habla que qualesquier bestias que fueren hallados en los panes, vinnas o higuerales o sotos o lugares arbolados incurran en pena de veynte maravedís por cabeça, moderaron la dicha pena en que no incurran en mas de diez maravedis por cabeça. Las quales escripturas hagan las personas arriba contenidas. 
A la quinta hordenança que habla sobre las penas y danno de los ganados de las carneçerias paresçio las que la dicha hordenança quede en su fuerça y vigor, con tanto que en la horden del escrevir se faga segun dicho es.

A la sesta hordenança que habla sobre el hurtar de la fruta o espigar o coger caracoles o otras cosas quedando la dicha hordenança en su fuerça y vigor, con tanto que en la horden del escrevir se haga segun dicho es.

(f. 1 v.) A la setena hordenança dixeron que era buena

A la otava hordenança que dize que puedan prendar a los dannadores dixeron que era buena.

\section{6-X-10: El corregidor ordena que se observen las ordenanzas de la huerta re- dactadas por el corregidor Pedro Gómez de Setúbal pese a que estaban pendientes de aprobación por los Reyes Católicos (AMMU, Leg. 4281, nº 77, 2 ff.).}

(f. 1 r.) En la noble çibdad de Murçia, lunes diez dias de otubre de IMCCCCXCVI annos.

El muy virtuoso y discreto sennor el liçençiado Fernando de Barrientos, corregidor y justiçia de la dicha çibdad de Murçia y de la dicha çibdad de Lorca y de sus tierras por el rey e la reyna nuestros sennores, por quanto el rey e la reyna, nuestros sennores, por vna su carta firmada de sus nonbres, mandaron al liçençiado Pero Gomez de Setubar, corregidor que fue de la dicha çibdad, que de en çiertas personas del regimiento e çibdadanos de la dicha çibdad hiziese çiertas hordenanças para la guarda y buena guardaçion de la huerta de la dicha çibdad, y aquellas fechas las enbiasen a sus altezas para (que) se confirmasen y aprouasen. Y entre tanto, el corregidor de la dicha çibdad proueyese y diese remate en la guarda de la huerta de la dicha çibdad, en tal manera que los dannadores y malfechores fuesen castigados segund mas largamente por en la dicha carta de sus altezas (se) qontiene. Las quales dichas hordenanças fueron fechas $y$ ordenadas por el dicho corregidor y regidores y çibdadanos de la dicha çibdad sobre mucho acuerdo y deliberaçion que para ello ouieron, y firmandose y aprouandose de las hordenanças antiguas açerca de lo susodicho antiguamente estauan fechas y aquellas fueron por la dicha çibdad aprouadas y enbiadas a sus alteças para que las confirmasen y aprouasen. Lo qual sus altezas no an podido ver ni hazer a cabsa de otros negoçios en (f. 1 v.) que sus altezas y los sennores del su muy alto consejo estan ocupados de mayor ynportançia.

$Y$ en este tienpo, los grandes dannos y robos de la dicha huerta no an çesado ni çesan de cada dia, antes los clamores dellos an creçido y creçen a cabsa que en la dicha huerta no ay personas que tengan cargo ni cuydado de la guardar ni mirar 
por los dannos que en ellas se hazen y asy mismo porque las penas por donde hasta agora se a regido son tan baxas y çeuiles que por themor dellas los malos no dexan de robar y talar los panes y esquilmos y frutas de la dicha huerta.

Por ende, el dicho sennor corregidor, por virtud del poder a el dado por la dicha carta $y$ prouision de sus altezas para proueher y dar remate en los dannos y talas de la dicha huerta, oydo el paresçer y platicas que sobre este caso muchas vezes con muchas personas a auido y an presentado lo que de todo ello es menester hazerse y proueherse para el remate dello, dixo que mandaua y mando que las dichas hordenanças que asy fuesen fechas y ordenadas por el dicho corregidor y regidores y jurados y çibdadanos de la dicha çibdad, juntamentemente, sean guardadas y cunplidas y pregonadas. $Y$ ninguna ni algunas personas (f. 2 r.) sea osado de yr ni pasar contra ellas ni alguna dellas, so las penas en ellas conthenidas. Las quales su merçed mandaria exsecutar con mucha dilijençia.

Y porque es neçesario que aya personas çiertas que tengan cargo y cuidado de guardar y mirar la dicha huerta y escreuir las penas y calonias que fallasen para que los dannadores fuesen castigados conforme a las dichas hordenanças, mandaua y mando que se arrendasen las dichas (penas) de la huerta con las dichas hordenanças en la persona que mas preçio por ellas diese. La qual dicha persona que asy la arrendase lleuase y lleue de las dichas calonias, que el por sy mismo o por sus conpanneros tuuiese y escriuiese, todas las penas conthenidas en las dichas sus hordenanças syn dar dellas parte a ninguna persona. Las quales dichas penas les seran luego exsecutadas $y$ el entregado dellas.

El qual, dicho arrendador que asy las dichas penas arrendase, sea obligado y se a de obligar a pagar todos los dannos que en la dicha huerta se hizieren en todo el anno de su arrendamiento (por la qual pueda fazer su) o dar el dannador que los fizo çierto y seguro conforme a la dicha hordenança antigua o pagar el danno por sy y por sus bienes. (f. 2 v.) Otrosy, porque la dicha huerta sea mas mirada y guardada que se nonbren y su merçed nonbrara çiertas personas que sean juramentados para que todas las calonias que vieren hazer las escriuan para que las penas en que cayeren, las quales hizieren sean exsecutadas conforme a las dichas hordenanças. Y destas todas penas lleue el arrendador de la dicha huerta la terçera parte, el tal juramentado la otra terçera parte y la otra terçera parte sea para el juez que lo exsecutare.

Otrosy, que qualesquier personas que touieren qualesquier heredamientos en la huerta y regadio de la dicha çibdad, o sus labradores o moços puedan escreuir qualesquier penas e calonias que se hazen en los dichos sus heredamientos y aquellas sean exsecutadas conforme a los dichos hordenanças, y sea la terçera parte para el que la escriuiere y la terçera parte para el dicho arrendador y la otra terçera parte para el açud. Por ende, sy algunas personas quisieren con las dichas hordenanças y condiçiones susodichas arrendar las penas y calonias de la dicha huerta vengalo diziendo que la exsecuçion de las dichas penas el dicho sennor corregidor lo hara e mandara hazer muy bien y syn ninguna dilaçion. 
Otrosy, que en los casos y calonias que a sabiendas fueren fechas por qualesquier personas por ellos mismos o por sus ganados o bestiares quede a saluo para que el dicho sennor corregidor demas y allende de las penas conthenidas en las dichas hordenanças proçeda contra ellos criminalmente commo fuere justiçia, segund la calidad de su yerro.

\section{8-IV-3, Memorial de 17 peticiones que los regidores Manuel Arróniz y Pedro Riquelme presentarán a los Reyes Católicos en las Cortes de Toledo de ese año, entre las que hay dos referentes al regadío (AMMU, Leg. 4281, $\mathbf{n}^{\mathbf{0}} \mathbf{8 0}^{71}$ ).}

(1 r.) Otrosy, aveys de fazer saber a sus altezas commo por su carta y mandado se fizieron y ordenaron en esta çibdad çiertas hordenanças, asy cerca de la guarda de la huerta commo sobre otras cosas tocantes a la buena gouernaçion desta çibdad, que las quales sus altezas mandaron que se les enviasen y esta çibdad las enbio para que las confirmasen e estan en poder de Alonso del Marmol, e nunca sus altezas an confirmado. Aueys de suplicalles ayan por bien de las aprobar y confirmar pues son tan justas y necesarias para el bien y vtilidad desta çibdad.

(4 r.) Otrosy, aueys de fazer (saber) a sus altezas commo muchos clerigos e personas eclesyasticas de ordenes an conprado e conpran en esta çibdad muchos heredamientos y bienes de lo realengo que es tributario al servicio de sus altezas, tanto que ya ellos estan heredados en muy grand parte de la huerta desta dicha çibdad. Y quando acaesçe que algún seruiçio esta çibdad a de fazer a sus altezas o para reparo de los adarves o por la presa del açud o por otras cosas que tocan son necesarias al bien vniversal desta dicha çibdad non quieren contribuir los dichos clerigos y personas eclesyasticas por los dichos sus heredamientos, ante se escusan diziendo que non son obligados por ser eclesyasticos. A cabsa de lo qual los vezinos desta dicha çibdad pagan mucho mas que pagarian en los tales seruiçios y otras derramas conçernientes $(4$ v.) al bien vniversal de la dicha çibdad porque se exiymen los tales bienes $e$ heredamientos a la dicha jurediçion real. Lo qual, segund las leyes destos reynos y los preuilejos desta dicha ibdad, non se puede nyn debe fazer. Aveys de procurar con sus altezas que manden que los dichos clerigos non conpren los dichos bienes $y$ heredamientos de lo realengo; y si lo conpraren que contribuyan e pechen, asy por lo que tienen conprado commo por lo que conpraren de aqui adelante, commo contribuyen los vecinos desta dicha çibdad, pues que los dichos heredamientos non son de sus rentas ni de la iglesia.

${ }_{71}$ Se transcriben solo las relacionadas con el regadío. 
1501 (fecha probable). Borrador del concejo de Murcia para que el rey ayude en las obras necesarias que se han de realizar para paliar las riadas (AMMU, Leg. 4276, $n^{0} 86 ., 1$ f.).

Muy poderosos sennores

El conçejo de la çibdad de Murçia con deuido acatamiento e reuerençia besamos las reales manos de vuestra alteza. A la qual suplicamos plega saber commo de largos tienpos aca esta çibdad resçibe grandes dannos de las auenidas que de antigo vienen por este rio, derramando por las huertas frutos y esquilmos della, de que se faze tan grand detrimento que apenas se cojen los frutos que en ella ay y commo esta tierra sea esteril y a ella acuden tarde los temporales y commo no tiene otro sustentamiento saluo las huertas. Y aquellas por las auenidas faltan de contino en esta çibdad, ay grandes neçesidades y grandes gastos, asy para el proueymiento della commo para los reparos e obras que se fazen. Auemos fecho algunos anparos para la defensa de las tales auenidas y para fazelllos y sostenellos se han fecho asaz costas, lo qual todo non nos puede defensar a los grandes dannos que deste rio nos vienen. Y mirando aquellos y el gran peligro en que la çibdad esta, que reçelamos y avn tenemos por cierto que si gruesa auenida viniese entraría el rio por esta çibdad e arranal commo otras vezes a fecho, y non bastaria los tales reparos fechos. Auemos mucho mirado e platicado de dar a este rio algunos despindientes e descansos; y commo nosotros, con nuestras particularidades, non nos podemos acordar commo y por donde los tales despindientes e descansos se deuan fazer, porque vmillemente suplicamos a vuestra alteza madar proueher en ello commo viere que cunple a su seruiçio e al bien e pro comun desta çibdad, mandando que las tierras y heredades que fuesen tomadas e ocupadas por donde se fizieren los sangreros e despindientes del rio, los duennos dellas sean satisfechos e pagados de su valor. Porque çertificamos a vuestra alteza, sy en esto non proueyese, esta çibdad, non se podra sostener, y de cabsa desto los vezinos e poblaçion della van disminuyendo y avn las rentas de la yglesya y de vuestra alteza menoscabando. Lo qual encargamos a la real conçiençia de vuestra alteza e dello resçibiremos bien e merçed.

Fecha de recepción: 20 de octubre de 2014

Fecha de aceptación: 14 de febrero de 2015 
